Modern Asian Studies 55, 4 (2021) pp. I065-IIII. (C) The Author(s), 2020. Published by

Cambridge University Press. This is an Open Access article, distributed under the terms of the Creative Commons Attribution licence (http://creativecommons.org/licenses/by/4.o/), which permits unrestricted re-use, distribution, and reproduction in any medium, provided the original work is properly cited.

doi:I0.I017/Soo26749X20000207 First published online i8 August 2020

\title{
The Roots of Comparative Alterity in Siam: Depicting, describing, and defining the peoples of the world, I830s-I850s*
}

MATTHEW REEDER

\author{
Asia Research Institute, National University of Singapore \\ Email: arimtr@nus.edu.sg
}

\begin{abstract}
This article identifies a moment of conceptual innovation - the I83os to the I85os - in which everyday artists and writers in Siam were tasked with creating comparative representations of the peoples of the world. Although their compositions took a variety of formats, they departed from earlier representations of alterity by devoting equal attention to each 'type', including the Thai themselves. This approach is best exemplified in three mid-nineteenth-century works: (I) a set of archetypal portraits of about 20 peoples painted on the shutters of a major Buddhist monastery, (2) sculptures of 32 peoples at the same monastery with a short poem describing each one, and (3) entries defining terms for peoples in an early Thai-Thai dictionary. The systematic formatting of these works drew on similar compositions circulating across the nineteenth-century globe. Yet, despite the presence in Bangkok of foreign interlocutors and imported books and prints, the mid-nineteenth-century compositions preserve ethnic tropes and practices of expression specific to Siam. In addition, the agents of intellectual innovation were not restricted to the usual princely or missionary protagonists. It was a motley cast of anonymous artists, local scholars, and middling officials who tapped traditional genres of composition and local markers of differentiation to render the peoples of the world as comparable, generic, and fixed.
\end{abstract}

* Many thanks to Leonard Andaya, Anne Blackburn, C. Patterson Giersch, Arthit Jiamrattanyoo, Irving Chan Johnson, Bruce Lockhart, Tamara Loos, Peera Panarut, Chairat Polmuk, Keith Taylor, and Chalermchai Wongrak for offering valuable comments on earlier drafts. Special thanks to Chairat Polmuk for advice on the translations and Arthit Jiamrattanyoo, Yangwon Hyun, and John S. F. Smith for accompanying me to Wat Pho, Wat Ko Kaew Suttharam, and Wat Bang Khun Thian Nok, respectively, and for help with the photographs. I also appreciate feedback from audiences at Columbia and Cornell. All errors are mine. 


\section{Introduction}

In the mid-nineteenth century, which here refers to the 25 years or so between the early I830s and the mid-1850s, a growing number of Siam's artists and writers endeavoured to represent the peoples of the world in a systematic fashion. ${ }^{1}$ In compositional forms ranging from paintings and sculptures to poetry and reference works, they depicted, described, and defined a panoply of peoples as discrete social types. Unlike the scattered representations of foreigners in earlier texts and art, these new compositions subjected categories of peoples - including the Thai themselves - to organized frameworks of presentation. ${ }^{2}$ They devoted equal attention to each representative figure, facilitating comparisons of cultural and physical alterity. Not unlike early reference works on comparative religion in Europe - which subordinated Christian beliefs to an objective structure of presentation that encouraged critics to compare and contrast religious practices across the globe - the systematic formatting of Siam's mid-century compositions made categories of peoples seem essentially equivalent. ${ }^{3}$ The literati of Bangkok had begun to imagine that the peoples of the world could be fitted into a 'totalizing classificatory grid'. In Siam, the modern understanding of the fundamental comparability of peoples can be traced to this moment.

${ }^{1}$ Following nineteenth-century English usage, Siam refers to the kingdom based at Bangkok and does not include tributary kingdoms and semi-autonomous cities on the kingdom's peripheries like Chiang Mai, Cambodia, and outer towns ruled by Malay and Lao nobles. Most of my discussion focuses on Bangkok.

${ }^{2}$ For seventeenth- and eighteenth-century depictions of alterity in Siam, see Maurizio Peleggi, 'The Turbaned and the Hatted: Figures of Alterity in Early Modern Thai Visual Culture', in Images of Otherness in Medieval and Early Modern Times: Exclusion, Inclusion and Assimilation, ed. Anja Eisenbeib and Lieselotte E. Saurma-Jeltsch (Berlin: Deutscher Kunstverlag, 2012); Somlux Khamtrong, 'Phap chao tang chat nai ngan jitrakam thai prapheni tang tae plai phutthasattawat thi 23 thueng phuttasattawat thi 24 ' ['The Foreigners Images in Thai Tradition Painting between Late I7-I8 Century A.D.'] (master's thesis, Silpakorn University, 2007), chapter 4.

${ }^{3}$ Lynn Hunt, Margaret C. Jacob, and Wijnand Mijnhardt, The Book that Changed the World: Picart and Bernard's Religious Ceremonies of the World (Cambridge: Harvard University Press, 2000); Margaret T. Hodgen, Early Anthropology in the Sixteenth and Seventeenth Centuries (Philadelphia: University of Pennsylvania Press, I964), I68-76. Bangkok intellectuals also began to treat religions comparatively in the late nineteenth century. See Thongchai Winichakul, 'Buddhist Apologetics and a Genealogy of Comparative Religion in Siam', Numen 62 (2015): 76-99.

${ }^{4}$ Benedict Anderson, Imagined Communities: Reflections on the Origin and Spread of Nationalism, rev. ed. (London: Verso, 2006), chapter Io. 
Historians often associate nineteenth-century attempts to order knowledge about the world's peoples with Europeans and Americans. Few Westerners resided long-term in Siam in the first half of the nineteenth century, however, and they had little direct influence on the kingdom's artists and writers. ${ }^{5}$ But avid creators of ethnographic-like knowledge also resided in China, Japan, the Ottoman empire, and elsewhere. As early as the sixteenth century, artists in China, Japan, Europe, and the Philippines were producing and reproducing visual typologies depicting dozens of peoples, side by side. ${ }^{6}$ By the early nineteenth century, systematic visual representations of the peoples of the world were bought and sold at major ports across the globe. Some of these trickled into Bangkok. At the same time, thousands of Chinese arrived every year. As a result, influences on Siam's artistic compositions were multiple and complex. Chinese reproductions of Western illustrations, for example, were common sights in Bangkok. ${ }^{7}$ Even as the city's artists and writers drew selectively from newly arrived

${ }^{5}$ Other than a handful of French priests often at odds with both the kingdom's rulers and their own mestizo parishioners, few Europeans even set foot in Bangkok between i765, when the Dutch factory closed, and the I820s. European and American trading ships called from time to time, but their unruly crews made a poor impression. A few diplomatic and trade representatives began arriving in the early 1820 s, followed by a smattering of merchants and missionaries. Even well into the I85os, however, the community of Europeans and Americans in Bangkok remained tiny. B. J. Terwiel, 'Mu'ang Thai and the World: Changing Perspectives in the Third Reign' (presentation at the seminar, Asia: A Sense of Place, Australian National University, Canberra, I4 March 1986); Edward Van Roy, Siamese Melting Pot: Ethnic Minorities and the Making of Bangkok (Chiang Mai: Silkworm, 2017), chapter 2. On new experiments in art during this period, see John Clark, 'Presenting the Self: Pictorial and Photographic Discourses in Nineteenth-Century Dutch Indies and Siam', Ars Orientalis 43 (2013): $7 \mathrm{I}^{-2}$.

${ }^{6}$ Laura Hostetler, 'Qing Connections to the Early Modern World: Ethnography and Cartography in Eighteenth-Century China', Modern Asian Studies 34, no. 3 (2000): 62362; Laura Hostetler, 'Introduction: Early Modern Ethnography in Comparative Historical Perspective', in The Art of Ethnography: A Chinese 'Miao Album', trans. David M. Deal and Laura Hostetler (Seattle: University of Washington Press, 2006); Farish A. Noor, 'You Are Under Arrest: Epistemic Arrest and the Endless Reproduction of the Image of the Colonised Native', South East Asia Research 24, no. 2 (2014): 185-203; Ann Laura Stoler, 'Rethinking Colonial Categories: European Communities and the Boundaries of Rule', Comparative Studies in Society and History 3I, no. I (I989): I34-6I; Ronald P. Toby, 'Imagining and Imaging "Anthropos" in Early-Modern Japan', Visual Anthropology Review I4, no. I (1998): I9-44.

${ }^{7}$ Jessica Lee Patterson, 'Chinese Glass Paintings in Bangkok Monasteries', Archives of Asian Art 66, no. 2 (2016): 153-85. Unlike some Western ideas and inventions, Chinese cultural imports were seen by locals as complementary to their own. Nidhi Eoseewong, 
books, prints, and interlocutors, their works still teemed with tropes, vocabulary, and markers of identification long found locally.

Three exemplary compositions illustrate the ways in which Bangkok's artists and writers combined innovation and convention: a set of portraits of about 20 peoples painted on the window shutters of a Buddhist monastery, verse inscriptions describing sculptures of 32 peoples elsewhere at the same monastery, and the entries for the names of peoples in a monolingual dictionary produced by native Thai-speakers under the supervision of the American missionary, Dan Beach Bradley. The monastery, Wat Phra Chetuphon, is a major Buddhist temple known colloquially as Wat Pho. Located just south of the Grand Palace in the heart of old Bangkok, it has enjoyed royal support since shortly after the capital was established in 1782. In the I83os and I840s, a major renovation filled the temple grounds and its public buildings with sculptures, murals, and inscriptions of an encyclopaedic nature. The renovations were conducted on the orders of King Rama III (r. I824-5I, the 'Third Reign') and under the watchful eye of the temple's abbot-prince. However, the artistic details were left to a broad assortment of anonymous artists and the textual details were composed by monks, scribes, and officials of all stations. Likewise, the definitions in Bradley's famous dictionary were not written by Bradley himself, but by a pair of local scholars assigned to do the work in the early i850s. These paintings, statues, and definitions of peoples were not the only ones produced in Siam during the mid-nineteenth century, but they are the most detailed and best documented. By taking a close look at their content, the circumstances of their production, and the sources they drew on, we can identify a meaningful shift toward the categorical representation of peoples in Siam.

These findings prompt a reconsideration of the conventional historiography of nineteenth-century intellectual change in two ways. First, while most research has focused on fields such as science, technology, geography, and medicine, where 'Western' and 'indigenous' forms may have been more easily distinguishable, knowledge about the peoples of the world was diffuse and more difficult to separate into endogenous and exogenous traditions. Unlike the scientific and technical knowledge that Bangkok intellectuals in this period associated with Europeans and Americans, knowledge about the peoples of the

Pen and Sail: Literature and History in Early Bangkok, ed. Chris Baker and Ben Anderson (Chiang Mai: Silkworm, 2005), 234-7. 
world was considered universal. The intellectual transition of the mid-nineteenth century was therefore one of quiet innovation as much as 'violent' displacement. ${ }^{8}$ Second, by attending to the creative and scholarly works of anonymous artists, mid-ranking officials, language teachers, and conservative princes, this article identifies a neglected set of historical figures as significant agents of intellectual change. In so doing, it diverts attention from the conventional historiographical heroes: the missionaries and their princely and monastic interlocutorsespecially Prince/King Mongkut (r. I85 $\mathrm{I}^{-68)}$ ). As seen from Bangkok, innovation in the production of knowledge about the world's peoples was incremental and dispersed.

\section{Wat Pho and the agents of intellectual change}

The mid-nineteenth century is often described as a transitional period in the intellectual history of Siam. In narratives of this transition, the chief protagonists are usually Prince Mongkut - a monk throughout the reign of his elder half-brother, King Rama III-and a fractious cast of Protestant missionaries who began arriving in 1828. Conversations between the missionaries, Prince Mongkut, and other Bangkok intellectuals, it is said, prompted a conceptual reorientation towards 'rational' modes of thinking current in the West. ${ }^{9}$ If this were the whole story, our account of Siam's mid-century transformation should begin

\footnotetext{
${ }^{8}$ Focusing on elite approaches to astronomy and geography, Thongchai Winichakul, Siam Mapped: A History of the Geo-Body of a Nation (Honolulu: University of Hawai'i Press, 1994), esp. chapter 2, argues that Western forms of knowledge displaced indigenous ones after a long nineteenth-century clash. Both Thongchai, p. 6r, and Nidhi, Pen and Sail, 236, portray this transition as epistemologically 'violent'. See also Thanet Aphornsuvan, 'The West and Siam's Quest for Modernity', South East Asia Research I7, no. 3 (2009): 4 OI- 32 .

${ }^{9}$ In matters of science, technology, medicine, and European languages, Mongkut and other prominent intellectuals came to respect, sooner or later, certain missionaries' expertise. In matters of religion, on the other hand, missionaries may have played the role of an 'irritant', in Tambiah's words, provoking local intellectuals to mount a vigorous defence of Buddhism. See S. J. Tambiah, World Conqueror and World Renouncer: A Study of Buddhism and Polity in Thailand against a Historical Background (Cambridge: Cambridge University Press, I976), 212-4; Davisakd Puaksom, Yod lueat jaruek lae thaen phim: waduai khwamru/khwamïng khong chon channam sayam pho so 2325-24II [Drops of Blood, the Inscription, and the Printing Press: On Knowledge/Truth and Siam's Elite, I782-I8687 (Bangkok: Illuminations Editions, 2018); Thanet, 'The West and Siam's Quest'; Thongchai, Siam Mapped, esp. chapter 2.
} 
with Mongkut's ordination and the missionaries' arrival in the I820s. But Mongkut would not have found textual orthodoxy so attractive, and the missionaries would not have found such ready conversation partners, if they were not building on local intellectual trends that date, at least, to the late eighteenth century. ${ }^{10}$

These older trends, in short, favoured reading over listening, the cosmopolitan over the insular, and the canonical over the mystical. Writers of the late eighteenth and early nineteenth centuries produced a vast new corpus of literature and reference works with readers in mind. They searched foreign and popular sources for storylines to invigorate court literature, their compositions featured realistic scenarios and cosmopolitan settings to appeal to a broader audience, and they wrote histories, treatises, and reference works designed for a growing cross-section of readers. ${ }^{11}$ Their emphasis on the written word was shared by Buddhist reformers, chief among them Mongkut's grandfather, King Rama I (r. I782-I809). The king is perhaps best known for convening a rare council of senior monks to purify the Pali canon through careful editing. But he also ordered scholars to translate and compose new works on Buddhist history and philosophy, and he issued a series of royal orders to discipline the monkhood by attacking supernaturalism and other pursuits unbecoming of monks. Few of the king's Ayutthaya-era predecessors had taken such steps. ${ }^{12}$ The king also made it a habit to put the moral and practical reasoning behind his decisions in writing; treatises and royal orders alike began to include explicit justifications. ${ }^{13}$ These long-term trends toward providing explanations, promoting textual authority, and looking outward for

${ }^{10}$ The most prominent advocate of viewing nineteenth-century intellectual developments in the context of long-term early Bangkok trends is probably Nidhi, Pen and Sail, esp. 3-4.

${ }^{11}$ Nidhi, Pen and Sail. Some of these trends may have predated the fall of Ayutthaya in I767; see Chris Baker and Pasuk Phongpaichit, A History of Ayutthaya: Siam in the Early Modern World (Cambridge: Cambridge University Press, 2017), 232-5.

${ }^{12}$ Nidhi, Pen and Sail, 278-82; Saichol Satayanurak, Phutthasatsana kap naewkhit thang kanmueang nai ratchasamai phrabat somdet phra phutthayotfa julalok [Buddhism and Political Thinking in the Reign of Rama I] (Bangkok: Matichon, 2003); Craig James Reynolds, 'The Buddhist Monkhood in Nineteenth Century Thailand' (PhD thesis, Cornell University, I972), chapter 2.

${ }^{13}$ David K. Wyatt, 'The "Subtle Revolution" of Rama I of Siam', in Studies in Thai

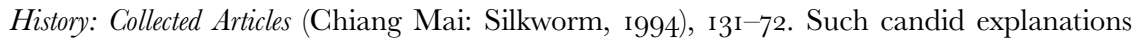
of the royal thinking were almost unheard of in the Ayutthaya era, but were emulated by his successors. 
inspiration laid the groundwork for Siam's intellectual transformations of the mid-nineteenth century. ${ }^{14}$

Mongkut rushed to ordain just before his father, King Rama II, died in I824. Wisely, he kept the robes as his older half-brother took the crown. He quickly developed a reputation for his mastery of Pali texts. Around I826, Mongkut began to see the Mon order as a model of canonical purity, and he redoubled his efforts to reform his own practice when he shifted monastic residences in I829. It was not until around I833, however, that Mongkut made a public break with mainstream tradition in Siam by organizing his own reordination. This event was later seen as the symbolic beginning of his Thammayut movement. In the next few years, Mongkut's handful of followers grew to a couple of dozens. ${ }^{15}$ As early as I830, Mongkut was exchanging knowledge with Jean-Baptiste Pallegoix, the priest of the church next door, and, throughout the r83os, he appears time and again in the journals and letters of Protestant missionaries. ${ }^{16}$ But even the missionaries declined to take credit for Mongkut's reforms, believing that they were made at the behest of Rama III, or at least with his approval. ${ }^{17}$ That approval was officially conferred in 1837, when the king awarded Mongkut an elevated title and made him abbot of Wat Bowonniwet, a royal monastery in central Bangkok.

With royal support, an institutional centre, and a growing number of lay and robed followers, Mongkut was no longer afraid of stepping on toes. He embarked on a dogmatic campaign, in Craig Reynolds's words, against

${ }^{14}$ Many of these trends can also be observed in Lanka and Burma. See Charles Hallisey, 'Roads Taken and Not Taken in the Study of Theravāda Buddhism', in Curators of the Buddha: The Study of Buddhism under Colonialism, ed. Donald S. Lopez, Jr (Chicago: University of Chicago Press, 1995), esp. 47-9; Tambiah, World Conqueror, 216-9.

${ }^{15}$ Reynolds, 'Buddhist Monkhood', 66-85.

${ }^{16}$ See, for example, Anthony Farrington, ed., Early Missionaries in Bangkok: The Journals of Tomlin, Gutzlaff and Abeel, I828-I832 (Bangkok: White Lotus, 200I); Dan Beach Bradley, Abstract of the Fournal of Rev. Dan Beach Bradley, M.D.: Medical Missionary in Siam 1835-I873, ed. George Haws Feltus (Cleveland: Dan F. Bradley, I936); and William L. Bradley, 'Prince Mongkut and Jesse Caswell', Fournal of the Siam Society 54, part I (I966): 29-4I. Pallegoix later wrote that Mongkut had 'patiently devoted' the 25 years before his accession to 'the study of Sanskrit, Pali, history, religion, geography, physics and chemistry, astronomy and, finally, of the English language'. Jean-Baptiste Pallegoix, Description of the Thai Kingdom or Siam: Thailand under King Mongkut, trans. E. J. Tips (Bangkok: White Lotus, 2000), 302.

${ }^{17}$ W. L. Bradley, 'Prince Mongkut and Jesse Caswell', 34. In fact, Mongkut's movement did not immediately enjoy the king's support. See Reynolds, 'Buddhist Monkhood', 65. 
'blind faith and lax discipline'. ${ }^{18}$ Until he softened in the waning days of the Third Reign, Mongkut was uncompromising about matters such as the proper pronunciation of Pali and the appropriate method of wearing the robes. He rejected narratives that he believed to be apocryphal, such as the popular stories of the Buddha's previous lives and the Traiphum cosmology. Instead, he sent to Lanka for manuscripts to compile a purer Pali canon and had his students study it intensely. He also corresponded actively with counterparts in Lanka, inquiring about colonial rule and defending his interpretation of canonical texts. So that lay followers would better understand the Dharma, the prince urged monks to preach more often, to use vernacular speech rather than Pali, and to avoid reading their sermons. He also printed religious pamphlets for distribution. ${ }^{19}$ With his emphasis on monastic discipline, rational explanation, and textual authority, Mongkut followed in his grandfather's footsteps.

At the same time, the outward-looking orientation of the royal court in the late eighteenth and early nineteenth centuries primed the next generation of intellectuals to seek knowledge from foreigners. The missionaries did not disappoint. They arrived in Siam not just with a zeal for proselytization and an eagerness to converse in Thai, but also with the training and expertise to expound on astronomy, medicine, mechanics, and, of course, European languages - knowledge they hoped would persuade listeners to accept a Christian metaphysics. They reported countless visits, dinner parties, and freewheeling conversations with some of Bangkok's most illustrious figures. ${ }^{20}$ The missionaries also

\footnotetext{
${ }^{18}$ Reynolds, 'Buddhist Monkhood', 63 .

${ }^{19}$ Nidhi, Pen and Sail, 282-6; Reynolds, 'Buddhist Monkhood', 86-Io3; Tambiah, World Conqueror, 208-I5.

${ }^{20}$ The first three Protestant missionaries - Karl Gutzlaff, Jacob Tomlin, and David Abeel - served in Bangkok off and on between I828 and I832. Jean-Baptiste Pallegoix, a French Catholic, arrived in I830. In 1833, a few American missionaries began arriving almost yearly, including Dan Beach Bradley and his wife in 1835. The men were well educated. Most had gone to college and seminary, and some, like Bradley, to medical school. On the conversations between the missionaries and Third-Reign intellectuals, see Craig J. Reynolds, 'Buddhist Cosmography in Thai Intellectual History', in Seditious Histories: Contesting Thai and Southeast Asian Pasts (Seattle: University of Washington Press, 2006), I72-5; and Terwiel, 'Mu'ang Thai and the World'. Missionary Jesse Caswell (quoted in W. L. Bradley, 'Prince Mongkut and Jesse Caswell', 39) relates that conversations with Prince Mongkut and his monastic colleagues proceeded 'without any restraint'. For the recollections of Jaophraya Thiphakorawong and Prince Damrong on their early conversations with missionaries, see Prince Damrong [Rajanubhab], 'Introductory Chapter', in Historical Sketch of Protestant Missions in Siam I828-I928, ed. George Bradley McFarland (Bangkok: White Lotus, I999), I-I5.
} 
supplied themselves with maps, charts, gadgets, manuals, and astronomical equipment intended to force their interlocutors to question their cosmological (and, thus, their religious) beliefs. Bradley's Thai translation of his colleague's manual on astronomy had a major impact on Bangkok's elite, even if no one converted. ${ }^{21}$ Conversations with the missionaries often became the talk of the town. ${ }^{22}$ They produced, in Thongchai's view, a 'seismic shift in the intellectual milieu'. ${ }^{23}$

On closer examination, however, this shift appears less dramatic. Scholarly accounts of Siam's mid-nineteenth-century intellectual transition tend to focus narrowly on Mongkut's orthodox movement or on fields such as science, geography, astronomy, and medicine. ${ }^{24}$ In addition, while the effect of 'Western knowledge' on the general worldview of the Third-Reign elite is difficult to pin down, its effect on the masses of monks, artisans, and commoners of the period remains all but unexamined. ${ }^{25}$ Even among the elite, the missionaries' most frequent conversation partners were Mongkut and his associates. Aside from the prince himself, these included his full brother, Prince Chuthamani, as well as the Phra Khlang minister (the official responsible for overseas foreigners) and his sons, his deputy, and the abbot of his monastery. The powerful Bunnag family, of which the Phra Khlang and his sons were members, were avid patrons of the Thammayut movement and were instrumental in putting Mongkut on the throne in $185 \mathrm{I}^{26}{ }^{2}$ Historians have therefore viewed the intellectual history of the mid-nineteenth century through the lens of factional

${ }^{21}$ Jacob Tomlin, 'Missionary Journals and Letters', in Early Missionaries in Bangkok: The Fournals of Tomlin, Gutzlaff and Abeel, 1828-1832, ed. Anthony Farrington (Bangkok: White Lotus, 200I), 27; Terwiel, 'Mu'ang Thai and the World', I8-23; Thongchai, Siam Mapped, 37; W. L. Bradley, 'Prince Mongkut and Jesse Caswell', 32, $3^{8 .}$

${ }^{22}$ For example, in $\mathrm{I} 844$, the missionaries learned of a conversation in which Mongkut, the Phra Khlang, and others discussed who among them 'had joined the missionaries' in believing Earth was a sphere. See the letter quoted in W. L. Bradley, 'Prince Mongkut and Jesse Caswell', $3^{8}$.

${ }^{23}$ Thongchai, 'Buddhist Apologetics', 79.

${ }^{24}$ See, for example, Reynolds, 'Buddhist Cosmography'; Thongchai, 'Buddhist Apologetics'; Thongchai, Siam Mapped; Thanet, 'The West and Siam's Quest'; and Quentin (Trais) Pearson, "Womb with a View": The Introduction of Western Obstetrics in Nineteenth-Century Siam', Bulletin of the History of Medicine 9o, no. I (2016): I- 3 I.

${ }^{25}$ For an effort to conceptualize the effect of 'Western knowledge' on the general worldview of the elite during the Third Reign, see Nidhi, Pen and Sail, 234-7.

${ }^{26}$ Terwiel, 'Mu'ang Thai and the World', I6-7; Robert Lingat, 'History of Wat Pavaraniveca', Fournal of the Siam Society 26 (1933): 87. 
politics. Mongkut and his supporters, open to the secular knowledge of the missionaries, represent the vanguard of intellectual transition. Princes and officials close to Rama III, in contrast, are portrayed as the conservative old guard, dismissive of the missionaries' expertise and resistant to change. It was only after Mongkut became king that the tide turned and Western approaches to scientific knowledge were accepted with halting consensus. ${ }^{27}$

If Siam's intellectual transition was born of engagements between Mongkut, his followers, and the missionaries, and was primarily observable in the fields of science, mechanics, and medicine, then how do scholars account for the most significant elaboration of knowledge in mid-century Siam? Beginning in 1834, an enormous collection of textual and visual compositions was installed at Wat Pho as the temple underwent a comprehensive overhaul. By the time renovations were complete in 1848 , inscriptions and murals covered the interior walls of almost every public building and hundreds of small statues dotted the galleries and grounds. The scope, number, and didactic purpose of the works have led scholars to see Wat Pho as a veritable 'encyclopedia' and a 'university in stone'. ${ }^{28}$ The works cover a vast array of sacred and secular subjects, including cosmography, astrology, omens, medicine, childbirth, massage, yogic positions, folktales, versification, provincial towns, the proper behaviour of women, the treatment of small-pox, the past lives of the Buddha, and the subject of this article: the diversity of the world's peoples. Even botanical gardens of medicinal plants were

${ }^{27}$ With respect to astronomy during the Fourth Reign, the process is detailed in Thongchai, Siam Mapped, chapter 2.

${ }^{28}$ For assessments of Wat Pho as like an encyclopaedia or a university, see Prince Damrong Rajanubhab, introduction to Prachum jaruek wat phra chetuphon [Inscriptions of Wat Pho], 1929 ed., cremation volume for Princess Suddhasininat Piyamaharaj Padivaradda (Bangkok: Sophonaphiphatthanakon, I929), i-iv; Prince Dhani Nivat, 'The Inscriptions of Wat Phra Jetubon', Journal of the Siam Society 26, no. 2 (1933): I43, I59, I63; and Davisakd Puaksom, Khon plaek na nana chat khong krung sayam nai 'khlong tang phasa' thi wat pho (University in Stone): ngan khian choeng chattiphan wanna (ethnography) chin raek khong sayam [The Foreign Strangers of Siam in the Khlong Poem on Foreign Peoples at Wat Pho, the University in Stone: Siam's First Work of Ethnography], ed. Sujit Wongthet (Bangkok: Sinlapa Watthanatham, 2003). On the didactic function of mural paintings in Siam's monasteries, see Reynolds, 'Buddhist Cosmography', i7ı. Dhani, 'Inscriptions', I46, gives 1835 as the year in which work began in earnest on the murals, inscriptions, and statues, but the contemporary evidence points to March i834. See Prachum jaruek wat phra chetuphon [The Epigraphic Archives of Wat Pho], 20II ed. (Bangkok: Wat Phra Chetuphon, 2011), 60-I, 318. 
laid to supplement inscriptions on treating ailments. ${ }^{29}$ Knowledge once transmitted through manuscripts and oral instruction was now displayed for public consumption. ${ }^{30}$ In this regard, Wat Pho's makeover was unquestionably innovative, but neither Mongkut, nor the missionaries, nor any of their confidants had any direct hand in it. On the contrary, it was Rama III who announced the renovations (as early as I83I), a prince later known as Paramanuchit Chinorot who presided over the monastery as abbot, and three officials close to the palace who oversaw the labour. How could the old guard be responsible for such an ambitious intellectual project? The conventional explanation views the renovations through the lens of Siam's political factions: Rama III ordered the production of artwork and texts to preserve 'traditional' knowledge in the face of a flood of 'foreign' ideas that threatened to swamp the kingdom in the Third Reign. ${ }^{31}$

But when we broaden our focus beyond the factionalism of the court, and beyond Mongkut and the missionaries, and beyond even the exemplary compositions produced at Wat Pho, the intellectual transition of the mid-nineteenth century appears more gradual, and its agents more diffuse. To begin with, the didactic compositions installed at Wat Pho in the mid-nineteenth century were not entirely unprecedented. The monastery already displayed knowledge about medicine and yogic positions as early as the First Reign and at least a handful of the temple's window shutters featured paintings of archetypal peoples no later than the Second. Even before the Third-Reign renovations, the monastery was known for its public orientation and instructive murals. ${ }^{32}$ In addition, Wat Pho held no monopoly on public

${ }^{29}$ Dhani, 'Inscriptions'.

${ }^{30}$ It was no coincidence, some argue, that knowledge was put on display at just the time that Protestant missionaries began their work in Bangkok. In contrast to the individual instruction offered by local elders and specialists, the missionaries made every effort to disseminate knowledge to anyone who would listen. See Damrong, introduction to Prachum jaruek, I929 ed., ii; Davisakd, Khon plaek na, I06-8; and Winai Pongsripian, 'Jaruek wat phra chetuphon: "khlong phap khon 32 phasa", moradok khwamsongjam haeng krung rattanakosin' ['Inscriptions of Wat Phra Chetuphon: "Poem on the Images of 32 Peoples", Heritage of Bangkok'], in Ioo ekkasan samkhan: sapsara prawattisat thai lamdap thi I8 [Ioo Key Documents: Essence of Thai History, no. I8] (Bangkok: Thailand Research Fund, 2012), 40-1.

${ }^{31}$ David K. Wyatt, Thailand: A Short History, 2nd ed. (Chiang Mai: Silkworm, 2003), I596o; Terwiel, 'Mu'ang Thai and the World', 26-8. See also Davisakd, Khon plaek na, Io8-I I.

${ }^{32}$ For the knowledge on display in the First Reign, see Winai, 'Jaruek', 39-40. John Crawfurd, a British envoy who visited Wat Pho in I82I, incorrectly believed that the 
displays of knowledge. Shortly before his death, Rama III had statues of rishis in yogic positions and inscriptions of medical inscriptions installed at Wat Bowonniwet, while painted portraits and statues of archetypal peoples, much like the ones on display at Wat Pho, were observed at other locations as well. ${ }^{33}$ Even the impact of displaying knowledge publicly may be overstated, as manuscript knowledge was more commonly accessed in the past. ${ }^{34}$

Furthermore, intellectual change was not the sole province of Mongkut and his associates. In fact, communication across class and factional lines was commonplace. For instance, some of the princes involved in the composition of inscriptions at Wat Pho, including Prince Paramanuchit and Prince Dechadison, were close to Mongkut as well as Rama III. Dechadison was also a frequent visitor of Bradley's. ${ }^{35}$ More importantly, anonymous artists and low-level monks, officials, and commoners played crucial roles in the production of knowledge. Their roles are especially

temple's formal name, Wat Phra Chetuphon, meant 'temple of the people' because it was 'accessible to every one'. In I832, the prince who gave missionary David Abeel a tour of Wat Pho indicated that its elaborate artwork aimed 'to instruct the illiterate through the medium of their senses'. The description of the visit by Jacob Tomlin, Abeel's colleague, gives a good sense of the public nature of the site. John Crawfurd, Fournal of an Embassy from the Governor-General of India to the Courts of Siam and Cochin China, 2nd ed., 2 vols. (London: Colburn and Bentley, I830), I: I63-72, quote on p. I64; David Abeel, 'Journal of a Residence in China and the Neighboring Countries', in Early Missionaries in Bangkok: The Fournals of Tomlin, Gutzlaff and Abeel $1828-18_{32}$, ed. Anthony Farrington (Bangkok: White Lotus, 200I [1835]), I42; J. Tomlin, Missionary Fournals and Letters Written during Eleven Years' Residence and Travels amongst the Chinese, Siamese, Favenese, Khassias, and Other Eastern Nations (London: James Nisbet and Co., I844), 354-9.

${ }^{33}$ For evidence that portraits of 'typical' peoples were painted on window shutters at other locations around this time, see the section on Wat Pho's shutter paintings, below. In I829, a French priest wrote that the inner palace gardens contained, among other representations of life outside the palace walls, 'models representing the different peoples on earth, with their individual shape and dress'. See Barthélemy Bruguière, 'Description of Siam in I829', trans. Kennon Breazeale and Michael Smithies, Fournal of the Siam Society 96 (2008): 157.

${ }^{34}$ Tambiah, World Conqueror, 206-7, observed that many men spent a good part of their ordained lives copying manuscripts of manual knowledge for future use as laymen. On 'manual knowledge', see Craig J. Reynolds, 'Thai Manual Knowledge: Theory and Practice', in Seditious Histories: Contesting Thai and Southeast Asian Pasts (Seattle: University of Washington Press, 2006), 2I $4-42$.

${ }^{35}$ Reynolds, 'Buddhist Monkhood', 73-4; D. B. Bradley, Abstract of the Fournal, 68-7I. Paramanuchit, on the other hand, had little time for Westerners. Just after the royal abbot's litter whisked past Crawfurd in the street, he rebuffed the British envoy's request for a meeting. Crawfurd, Journal of an Embassy, I: I72. 
clear in the creation of textual and visual knowledge about non-scientific matters such as the diversity of the world's peoples. Such actors can be identified with the creation of all three works discussed in this article: the mural paintings on the temple shutters, the poems and the statues they described, and the definitions in Bradley's dictionary. Though courtly, monastic, and missionary figures probably determined the comparative formatting of each of these works, it was a broad cross-section of artists and writers that domesticated the foreign by reviving old tropes, interpreting new information, and adapting traditional forms of expression. By investigating the form, the content, and the creators of Bangkok's mid-century efforts to depict, describe, and define the peoples of the world, it becomes clear that Siam's intellectual transition had deep historical roots and its agents spanned the social spectrum.

\section{Portraits of peoples on the shutters of Wat Pho}

The most vivid of the mid-century works are the figures painted on the window shutters of the assembly halls (viharas) at Wat Pho. Approximately 20 pairs of life-sized, full-body portraits survive on the inner surfaces of shutters in the temple's north, south, and west viharas (Figure I). ${ }^{36}$ The figures occupy the positions of temple guardians, which may explain why all the figures are male and many carry weapons. ${ }^{37}$ But the portraits do not depict particular individuals. Rather, they depict conventional types - archetypal categories that today might be considered 'ethnic' or 'national'. Viewed altogether, the shutter portraits form a typology - a series of discrete, stereotyped models of various peoples for visual perusal. ${ }^{38}$ The figures on the shutters are not labelled, and perhaps never were, so it is not always possible to identify with certainty the peoples depicted. However, each

${ }^{36}$ Photographs of some of the portraits are published in Kanjanakkhaphan (Khun Wichitmatra), Phumisat wat pho [Wat Pho Geography], vol. I (Bangkok: San Sawan, I966), ix-xvi; and Winai, 'Jaruek', I04-42. Kanjanakkhaphan's images show the paintings before their recent restoration, while Winai's show them afterwards. Winai labels the peoples in each portrait, but some of these attributions are dubious.

${ }^{37}$ K. I. Matics, Introduction to the Thai Mural (Bangkok: White Lotus, I992), 34; Fitrakam fa phanang nai prathet thai chut thi 002 lem thi 4: wat saket ratchaworamahawihan [Murals in Thailand, set 2, volume 5: Wat Saket Ratchaworamahawihan] (Bangkok: Fine Arts Department, I992), 62.

${ }^{38}$ I have been unable to determine whether, in the mid-nineteenth century, the buildings that hosted these shutters were always open to the public, or whether they were only unlocked on special occasions. 


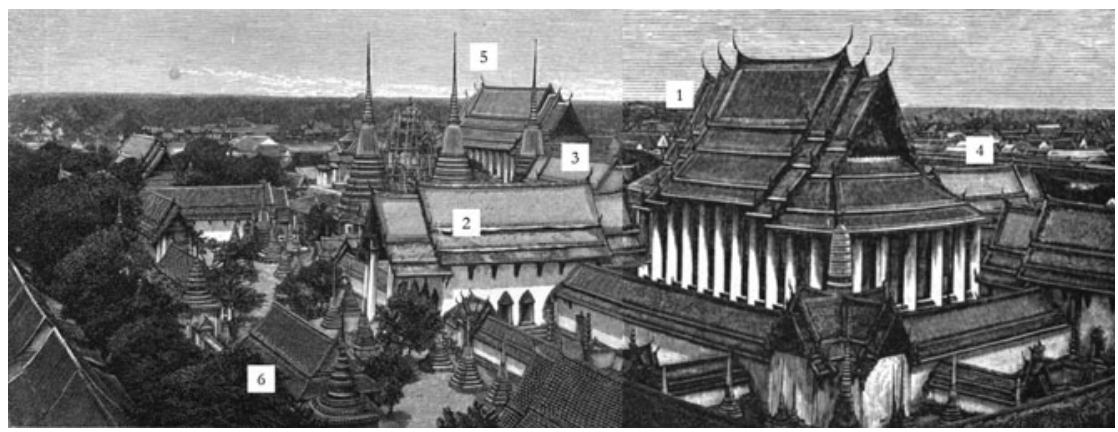

Figure I. Composite view of Wat Phra Chetuphon (Wat Pho) from the south-east. The large building on the right $(\mathrm{I})$ is the ordination hall (ubosot). Four viharas (assembly halls) radiate from the ordination hall in cardinal directions. Clockwise from the left, they are the south (2), west (3), north (4), and east viharas. Behind the south and west viharas are funerary stupas for Kings Rama I, II, and III. In this illustration, the stupa for King Mongkut, just beyond, is still under construction. The large building behind the funerary stupas contains Wat Pho's reclining Buddha (5). Sixteen pavilions lined the outer walls of the monastery's public grounds; one is marked (6). This image is a composite of two line drawings based on a panoramic set of photographs. Sources: The photographs have been attributed to Francis Chit and dated to I864 by Pipat Pongrapeeporn, Phap mum kwang khong Krung Thep Maha Nakhon nai samai ratchakan thi si: kankhonphop mai / Panorama of Bangkok in the Reign of King Rama IV: A New Discovery (Bangkok: Muang Boran, 200I). The line drawings were published in Frank Vincent, The Land of the White Elephant: Sights and Scenes in South-Eastern Asia (New York: Harper \& Brothers, I874), aft. 124, I28.

pair is given distinctive markers of identification - clothing, accessories, props, hairstyles, and facial features - many of which were well-established tropes in the artwork of Siam. By repeating them again and again in visual media, artists revived and reconfirmed locally specific conventions for differentiating peoples. This was not unusual: the frequent repetition of such markers with little concern for accuracy was consistent with typologies of peoples produced throughout Asia and Europe in the eighteenth and nineteenth centuries.

The north, south, and west viharas were built during the reconstruction of the temple ordered by King Rama I (r. I782-I809) in I788. According to an inscription commemorating the First-Reign construction work, the interior walls of the north vihara already featured a depiction of the Traiphum cosmography - a traditional conceptualization of the worldly and divine spaces of the universe. ${ }^{39}$ Around that time, it is possible that

${ }^{39}$ Prachum jaruek, 201 i ed., 56; Dhani, 'Inscriptions', I44. On the Traiphum cosmography, see Thongchai, Siam Mapped, chapter I. Although Wat Pho was first built in the Ayutthaya era $\left(\mathrm{I} 35^{\mathrm{I}-\mathrm{I}} \mathrm{7} 67\right)$, nothing from that period remains. 
portraits of some peoples were painted on the shutters of that vihara, as well. Visiting in 1822, the British envoy John Crawfurd observed the Traiphum mural. He reported that the walls of the north vihara 'contain representations of the Hindoo creation, and full-sized figures of the natives of Lao, Pegue, China, Tartary, Hindustan, and Persia'. ${ }^{40}$ Although this is not certain, Prince Dhani Nivat and others have taken Crawfurd's 'full-sized figures' to be a reference to the shutter paintings. ${ }^{41}$ As art historian K. I. Matics points out, 'the depiction of people from all corners of the world is appropriate for the Traiphum theme which includes all forms of existence'. ${ }^{42}$ David Abeel, one of the earliest Protestant missionaries in Bangkok, may have observed the same room in 1832 . He wrote that the walls were 'completely covered with representations of heaven, earth, hell, and one of the stars of which their books speak', but he also noticed 'foreigners, or caricatures of white men, and dignified natives', alongside other figures and scenes. ${ }^{43}$

Unlike the Traiphum murals, the figures on the shutters survive, but they are not necessarily in their original form. The portraits seen by Crawfurd were retouched, if not repainted completely, during the renovations of Rama III in the r83os and I840s. At around the same time, additional portraits were painted on other shutters in the north, south, and west viharas. The pair of Europeans visible today in the north vihara must have been among the new figures added in the mid-nineteenth century because, as Dhani observes, Crawfurd would certainly have mentioned them if they were present in I822. In addition, Crawfurd says nothing about the portraits that now decorate the shutters of the south and west viharas, even though he also visited those rooms. So, they too were probably painted later - in the i83os or i84os. Finally, we know that additional rooms were added to the three viharas in the reign of Rama III, so the shutters in those rooms cannot date earlier than the I830s. ${ }^{44}$ Since then, the shutters have been restored at least twice. So, while Crawfurd's observations suggest that some of the portraits were painted before I822 - possibly in the reign of Rama I - most of today's extant portraits must be touched-up versions of originals painted in the 1830 s or I840s.

${ }^{40}$ Crawfurd, Fournal of an Embassy, I: I66.

${ }^{41}$ Dhani, 'Inscriptions', I52.

${ }^{42}$ Matics, Introduction to the Thai Mural, 40.

${ }^{43}$ Abeel, 'Journal of a Residence', I42. It is not clear whether the 'foreigners' and 'dignified natives' he saw were on the shutters or in mural scenes.

${ }^{44}$ Dhani, 'Inscriptions', I46-52; Prachum jaruek, 201 I ed., 63. 
We cannot analyse the form and content of the shutter portraits without first considering the global circulation of visual typologies of the world's diverse peoples, the appearance of foreign-made portraits in Siam, and the local practice of depicting foreigners as guardian deities in local temples. Although there is no clear evidence that systematic visual typologies of peoples were produced in the kingdom before the Third Reign, examples of such works had been circulating in Asia since at least the end of the sixteenth century. Many were originally commissioned by imperial authorities, both Asian and European. As early as the I590s, for example, the Spanish governor of Manila hired Chinese artists to paint approximately 75 pictures of various peoples and professions in a book-length manuscript later called the Boxer Codex. The Dutch East India Company merchant, Johan Nieuhof, included nearly a dozen pictures of diverse figures - singly or in pairs - in his I682 account of the East Indies. Crawfurd's account of his mission to Siam included portraits of supposedly typical Malay, Thai, and 'Cochinchinese' couples, as well as profile illustrations of eight 'national' types. ${ }^{45}$

The late Ming and Qing imperial courts were also interested in depicting the variety of peoples they encountered. Scholar-officials in frontier districts created so-called Miao albums, which not only portrayed Miao (Hmong) groups, but also included dozens of other peoples living on the empire's southern and south-western frontiers. Based on these and other sources, the Qianlong emperor commissioned a more formal album in $175^{\mathrm{I}}$ in which the full variety of 'tributary peoples', including Europeans, were depicted side by side in malefemale pairs for comparison. The production of Miao albums peaked in the late eighteenth and early nineteenth centuries. ${ }^{46}$

Illustrations of generic peoples may have originally been based on real-life observations, but they were easily carried, copied, recoloured, adapted, and exaggerated by artists and publishers who had never met their subjects. European publishers sacrificed up-to-date accuracy for profit and expedience, continually reproducing the same illustrations in new publications. Nieuhof's prints, for example, were repeatedly copied and republished, in some cases more than a century after they were first

${ }^{45}$ John N. Crossley, 'The Early History of the Boxer Codex', Fournal of the Royal Asiatic Society, series 3, 24, no. I (2014): II5-7; Noor, 'You Are Under Arrest', I90-5; Crawfurd, fournal of an Embassy.

${ }^{46}$ Hostetler, 'Introduction', xvii-xxxix. 
made. Pictures highlighting 'native savagery' were especially popular; Nieuhof's print, 'A Soldier of Amboina', was reproduced again and again because, behind the soldier, two children are shown scalping a severed head. ${ }^{47}$ Imagery circulated from Asia to Europe and then back again. The European publisher, Willem Blaeu, for instance, collected illustrations of peoples from various sources and reproduced them, in dozens of male-female pairs, in a rough civilizational order around his maps of the world. As early as the beginning of the seventeenth century, Japanese artists saw such typologies and began producing their own versions on painted screens. At first, Japanese artists faithfully reproduced the European illustrations, even copying the distorted figures of the Japanese themselves. By the mid-seventeenth century, however, they were painting all the figures in a Japanese style. They also rearranged the order, leading off with a complimentary portrait of a dignified Japanese couple and finishing with faraway peoples with darker skin, less clothing, and an abundance of hair. ${ }^{48}$ In China, too, workshops began churning out lower-quality Miao albums for local consumers. The artists might have used stencils to facilitate mass production, as the outlines of the illustrations in different albums were identical, even as the painted details differed. Many of the details, in turn, were adjusted to appeal to the market. Some artists, for example, exaggerated hairstyles to match consumer tastes for the exotic and the skirts of some Miao women receded scandalously as prurience eclipsed accuracy. ${ }^{49}$

By the early nineteenth century, the global market for albums, illustrated books, paintings, and prints featuring arrays of 'exotic' peoples was livelier than ever. Artists in Asian port cities-including Canton and Manila - created paintings of figures representing a variety of peoples and professions to sell locally and to export for buyers around the world. Workshop artists relied on subtle printed outlines, or they traced figures through glass or thin paper, to facilitate mass production. Chinese artists became well known for copying prints and paintings from both Asian and European sources. Among these were albums depicting, in tabular formats, the costumes of peoples from around the world. ${ }^{50}$ By the mid-nineteenth century, the constant

${ }^{47}$ Noor, 'You Are Under Arrest', 193-5.

${ }^{48}$ All believed to be characteristics of savagery. See Toby, 'Imagining and Imaging'.

${ }^{49}$ Hostetler, 'Introduction', xxiv-xxix.

${ }^{50}$ Florina H. Capistrano-Baker, 'Trophies of Trade: Collecting Nineteenth-Century Sino-Filipino Export Paintings', Archives of Asian Art 67, no. 2 (2017): 237-56; Patterson, 
duplication of tropes, and their association with various peoples, had become a global phenomenon. In the popular imagination of viewers, wherever they lived, the repetition of certain identifying markers contributed to the formation of static stereotyped images of peoples. ${ }^{51}$ Illustrated typologies such as these likely found their way to Siam, although there is little direct evidence until the i83os, when books such as Crawfurd's appeared in the personal libraries of princes and high officials. ${ }^{52}$

Though not necessarily in tabular formats, portraits of foreigners had long been brought to Siam from a variety of sources. A Persian visitor reported in 1686 that King Narai (r. I656-88) was 'eager to learn about the other kings of the inhabited world, their behaviour, customs and principles. He made a great effort to enlighten himself and sent everywhere for pictures depicting the mode of living and the courts of foreign kings' ${ }^{53}$ According to the visitor, Narai was so struck by a portrait of the Safavid emperor that he decided to adopt Persianate dress himself. King Louis XIV of France sent a large portrait of himself to Narai as a gift and pictures of the Sun King and his family could also be viewed, at the time, in the residences of the Phra Khlang and Narai's Greek minister, Phaulkon. ${ }^{54}$ By the early nineteenth century, foreign-made prints were hung in monasteries all over Bangkok. At Wat Pho, Crawfurd observed 'several Chinese copies of French and English prints' decorating the walls of the north vihara. One of them, he added, was 'the portrait of an English lady- "la pensive

'Chinese Glass Paintings'; Karl L. Crossman, The Decorative Arts of the China Trade: Paintings, Furnishings, and Exotic Curiosities (Woodbridge, Suffolk: Antique Collector's Club, I99I), chapters 7,8 .

${ }^{51}$ Hostetler, 'Introduction', xxvi-xxvii; Noor, 'You Are Under Arrest', $201-2$.

${ }^{52}$ By i839, for example, Prince Chutamani had acquired a copy of Crawfurd's account with its typological portraits, a collection of (genuine) English prints, and an edition of the Encyclopaedia Britannica. Terwiel, 'Mu'ang Thai and the World', 24, n. 62; David Richardson, Dr. Richardson's Missions to Siam, I829-I839, ed. Anthony Farrington (Bangkok: White Lotus, 2004), I94, 207. Winai, 'Jaruek', 42, believes that Rama III may have derived inspiration or models for the shutter paintings from Chinese sources, which implies that the king himself came up with the subject matter for the shutters, but there is no clear evidence for either supposition.

${ }^{53}$ Ibn Muhammad Ibrahim, The Ship of Sulaiman, trans. John O'Kane (New York: Columbia University Press, I972), 99.

${ }^{54}$ Narai's portrait of Louis XIV did not last long - it was burned in his funeral pyre. Dirk van der Cruysse, Siam and the West I5OO-I700, trans. Michael Smithies (Chiang Mai: Silkworm, 2002), 265, 340, 468; Engelbert Kaempfer, A Description of the Kingdom of Siam I69o, trans. John Scheuchzer (Bangkok: Orchid, I998 [1727]), 38. 
Anglaise!" ${ }^{55}$ The surgeon George Finlayson, who accompanied Crawfurd, remarked that they 'were amused to find suspended in a very handsome temple, two coarse paintings of French ladies, in rural costume'. ${ }^{56}$ Although it is not clear whether Siam's temple artists would have seen visual typologies of peoples before the early to mid-nineteenth century, they were certainly exposed to imported portraits of foreigners.

While the portraits of almost two-dozen pairs of archetypal figures at Wat Pho exemplify the mid-nineteenth century trend toward comparative depiction, the decision to position them on the window shutters built on an old, local practice. As early as the seventeenth century, foreigners were sometimes depicted as temple guardians around doors and windows. Although guardians were more commonly given the form of ogres $(y a k)$, celestial deities, animals, and Chinese gods, there is some evidence that portraits of individual foreigners served as guardian figures towards the end of the Ayutthaya period

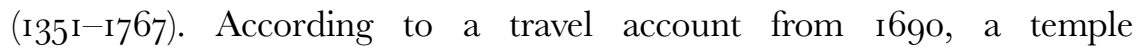
patronized by the Phra Khlang of the time featured, on the front doors, 'two Savages with the heads of Devils, and at the back door were painted two Portugueze as big as the Life'. ${ }^{57}$ Some of the king's royal guard were of Portuguese descent and so it might have seemed appropriate to depict them as temple guards even though they were Christians. Elsewhere, at Wat Tapon Noi in Chanthaburi, painted figures of a European - possibly Portuguese - and one or two others stand guard next to the windows. ${ }^{58}$ Then, around the turn of the eighteenth century, portraits of a Chinese, a European, and two Muslims were painted lurking above the windows at Wat Yai Suwannaram, Petchaburi. Murals dated 1734 at the nearby Wat Ko

${ }^{55} \mathrm{He}$ saw Chinese copies of European prints at other temples, too, and stated that 'in Siam they are very frequent'. Crawfurd, Journal of an Embassy, I: I67, 202-3; Patterson, 'Chinese Glass Paintings', I63-5.

${ }^{56}$ George Finlayson, The Mission to Siam, and Hué, the Capital of Cochin China, in the Years I82I-2 (London: John Murray, I826), 218. He does not say so clearly, but these paintings were likely observed at Wat Pho.

${ }^{57}$ Kaempfer, Description of the Kingdom, 62. Kaempfer includes a drawing of one of the 'Savages with the heads of Devils'. It is difficult to say whether the 'savages' are ogres or people. See also John Andrew Listopad, 'The Art and Architecture of the Reign of Somdet Phra Narai' (PhD thesis, University of Michigan, I995), 217-8.

${ }^{58}$ A seventeenth-century date for the figures is proposed by No na Paknam, 'Jittrakam fa phanang phra ubosot wat tapon noi... janthaburi' ['The Mural Paintings of Wat Tapon Noi, Chanthaburi'], Muang Boran I5, no. 4 (Oct-Dec 1989): 9o-6. See also Gerhard Jaiser, Thai Mural Painting, 2 vols. (Bangkok: White Lotus, 2009, 2010), I: 87-8, II: 66. 
Kaew Suttharam include a series of figures, wearing diverse costumes, floating under the eaves. ${ }^{59}$ Though the Phra Khlang's temple does not survive, the figures at the other monasteries seem to display the idiosyncratic features and sartorial details of specific individuals, not generic types. The features of the European at Wat Yai Suwannaram can even be traced, plausibly if not certainly, to a portrait of Britain's King James I, a copy of which may have made its way to Siam via the Mughal empire. ${ }^{60}$ Unlike the figures at Wat Pho, however, only foreigners with fearsome reputations were selected to guard Ayutthaya-era temples. They were not archetypal portraits displayed for public instruction and comparison.

If the painters responsible for Wat Pho's shutter portraits were the same as those assigned to the mural paintings on the surrounding walls, they were members of the royal artist corps. ${ }^{61}$ While they were exposed to foreign-made portraits, they did not, it seems, use those illustrations as models for their shutter paintings. Neither did they rely on their own observations of the cosmopolitan residents around them. Instead, they drew on locally familiar tropes and stock images of foreigners. Indeed, some markers of identification changed little from the late seventeenth century to the mid-nineteenth. It is possible, as Matics suggests, that 'eclectic artisans were following Ayutthaya [period] models from iconographical sketchbooks. ${ }^{62}$ The artists also surely observed examples of stock characters on temple walls throughout the city. One of the clearest examples is the figure of a particular variety of European, usually identified by later scholars as French or Dutch. In murals of the

${ }^{59}$ See Wannipha na Songkhla, ed., 'Wat Ko', in Wat ko jangwat phetburi [Wat Ko, Phetchaburi Province], ed. Bunmi Phibunsombat (Phetchaburi: Petchpoom, 200o), I04.

${ }^{60}$ Michael Wright, 'Than khoei hen na 'farang' khon ni mai? Khon thi yu nai bot wat yai suwannaram mueang petchaburi' ['Have You Seen the Face of this "Farang" Before? The Person in the Ordination Hall at Wat Yai Suwannaram, Petchaburi'], Sinlapa Watthanatham 24, no. 6 (April 2003): 99-10I. See also Listopad, 'Art and Architecture', 350-7.

${ }^{61}$ Rama III embarked on so many temple-renovation projects simultaneously that the supply of royal and monastic artists was insufficient. Chinese artisans and artisans serving other nobles - many of whom were more skilled than the royal artists - were hired to work on Wat Pho as well. A poem by Prince Paramanuchit tells us that the murals in the three directional viharas were painted by palace artists, though it is not certain that they also painted the window shutters. Saran Thongpan, 'Chiwit thang sangkhom khong chang nai sangkhom thai phak klang samai rattanakosin kon pho so 2448' ['The Social Lives of Artisans in Central Thai Society in the Bangkok Period before I905'] (master's thesis, Thammasat University, I99I), 87-93. Thanks to John Clark for bringing this thesis to my attention.

${ }^{62}$ Matics, Introduction to the Thai Mural, 37. 
eighteenth and early nineteenth centuries, this sort of European generally wears a wig with long curls, a black hat with an upturned brim, a frilly cravat and cuffs, and a long colourful coat. ${ }^{63}$ Popular among European gentlemen from the late seventeenth to the mid-eighteenth centuries, this attire was decidedly old-fashioned by the end of the eighteenth and was comically outdated by the mid-nineteenth. Yet these markers were still used to depict the figure of the Dutch or French European at Wat Pho and elsewhere in Siam.

A pair of Europeans on the Wat Pho shutters (Figure 2) includes all these markers. They closely resemble Europeans depicted a century prior on the walls of Wat Ko Kaew Suttharam, Phetchaburi, and in a late Ayutthaya-era pavilion now located at the Suan Pakkat Palace in Bangkok. Even though a Jesuit priest in the Wat Ko Kaew mural has dressed himself as a Buddhist monk (Figure 3, at far right), he is nevertheless rendered identifiably European by his hat and wig-clues that ensure his correct identification. ${ }^{64}$ In addition, the left-hand figure in the pair of Europeans on Wat Pho's shutters strongly resembles a European depicted on a famous lacquer cabinet of uncertain date housed in the Bangkok National Museum (Figure 4). Both figures adopt a stance popular in late seventeenth-century French royal portraiture: each figure's weight rests on his forward left foot, while the right foot is tucked behind. His left hand rests on his hip while his right holds a weapon. Art historians have argued that the prototype for these two figures, and for the representation of this type of European in Siam generally, may have been the portrait of Louis XIV given to Narai. ${ }^{65}$

${ }^{63}$ No na Paknam, Farang nai Sinlapa Thai [Westerners in Thai Art] (Bangkok: Muang Boran, 1986). Here, I describe the common tropes for the European figure that appeared most often on temple walls and that was probably based on the French or the Dutch. However, other European, Portuguese, and local Christian figures can be found in murals, sporting somewhat different markers. For a good sense of the variety of European types, see Jaiser, Thai Mural Painting, II: 65-73.

${ }^{64}$ No na Paknam, Farang nai Sinlapa Thai, 32-7; Jaiser, Thai Mural Painting, II: 65-73; Peleggi, 'Turbaned', 6I-3. The murals at Wat Ko Kaew Suttharam are dated I734.

${ }^{65}$ Forrest McGill, ed., The Kingdom of Siam: The Art of Central Thailand, 1350-I80o (San Francisco: Asian Art Museum, 2005), 155-8, suggests a seventeenth-century date for the lacquer figures on the cabinet doors, but Listopad, 'Art and Architecture', 31 I-2, believes a late eighteenth- or early nineteenth-century date more likely. In addition to the main figure on each door, five smaller figures - two of them identifiably European and two Chinese - take the form of winged deities in the clouds above. See Hiram Woodward, 'The Louis XIV Manuscript Cabinet: The Role of Thunder and Lightning', Fournal of the Siam Society I05 (2017): I3I-40. 


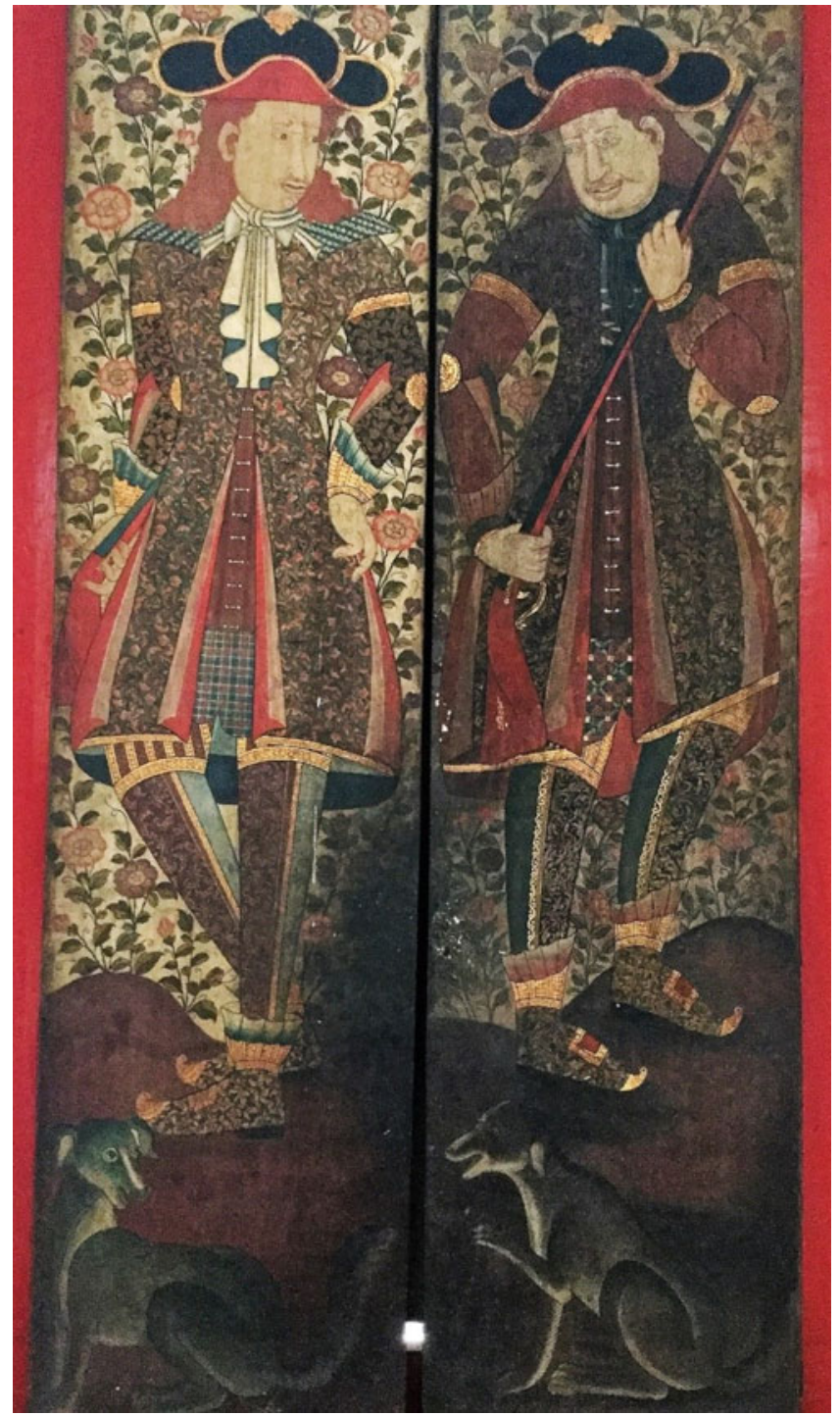

Figure 2. Portraits of Europeans - perhaps French or Dutch — painted on the shutters of one of the directional viharas, Wat Pho. Source: Arthit Jiamrattanyoo.

The stock figure of a Muslim in Persianate dress also appears frequently in eighteenth- and early nineteenth-century murals. Wearing a turban, slippers, and a colourful robe, he may represent Persians, Indo-Persians, or another sort of Muslim from Southern Asia. Next to the Louis-like European on the doors of the lacquer cabinet is a Muslim figure of this 


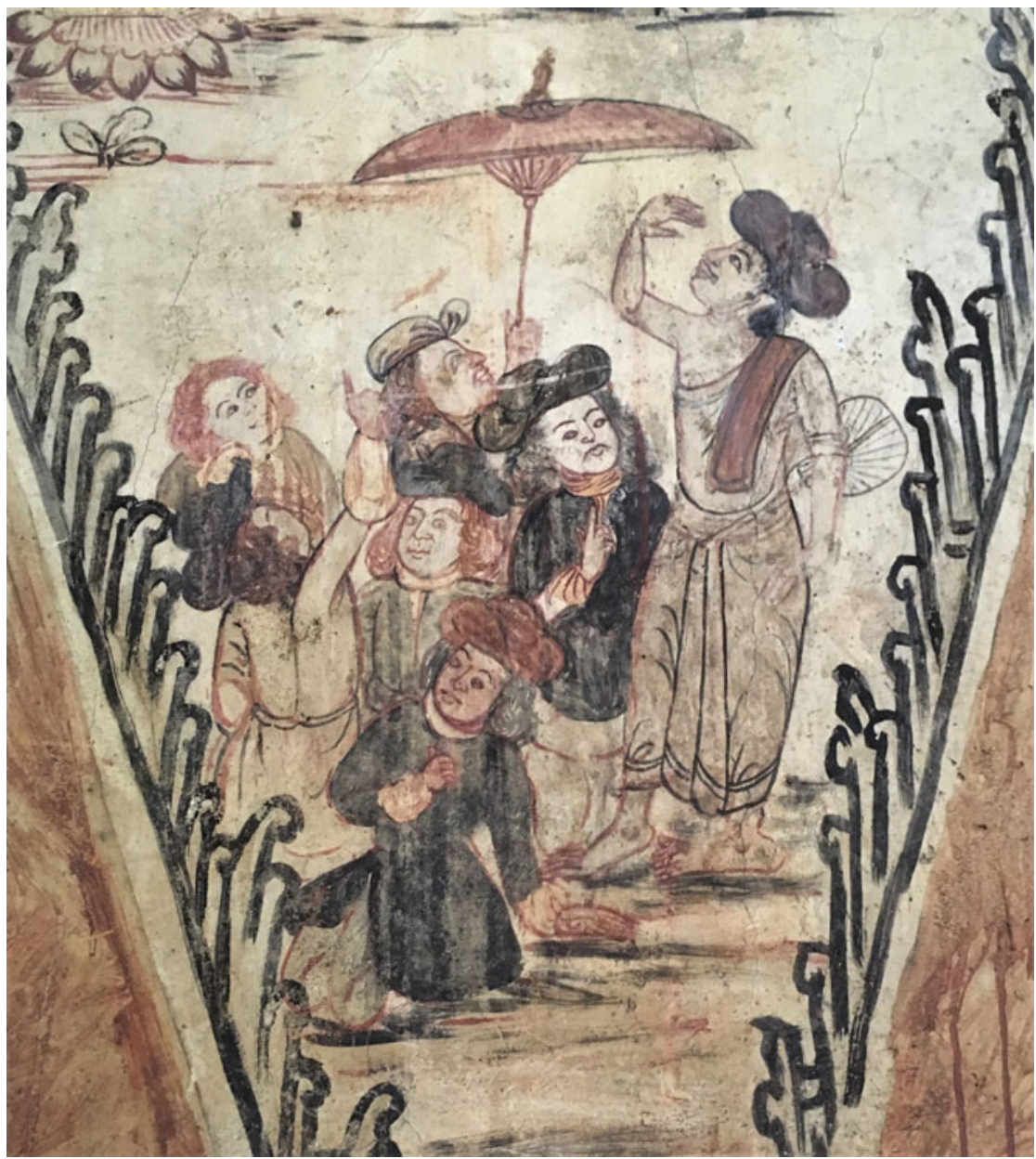

Figure 3. Detail of Europeans, including one dressed like a Buddhist monk, in a mural dated I734, Wat Ko Kaew Suttharam, Petchaburi, Thailand. Source: Matthew Reeder.

type (Figure 4). His pose, like his partner's, resembles one of the portraits at Wat Pho, but other props differ (Figure 5). The shutter figure's sword and sash appear to match the Indo-Persian style more closely than the cabinet figure's kris and belt. ${ }^{66}$ Persianate Muslims with sashes and swords also appear in other eighteenth- and early nineteenth-century

${ }^{66}$ McGill, ed., Kingdom of Siam, I55-6; Woodward, 'Louis XIV Manuscript Cabinet', I40. The kris is associated with the Malay Archipelago. 


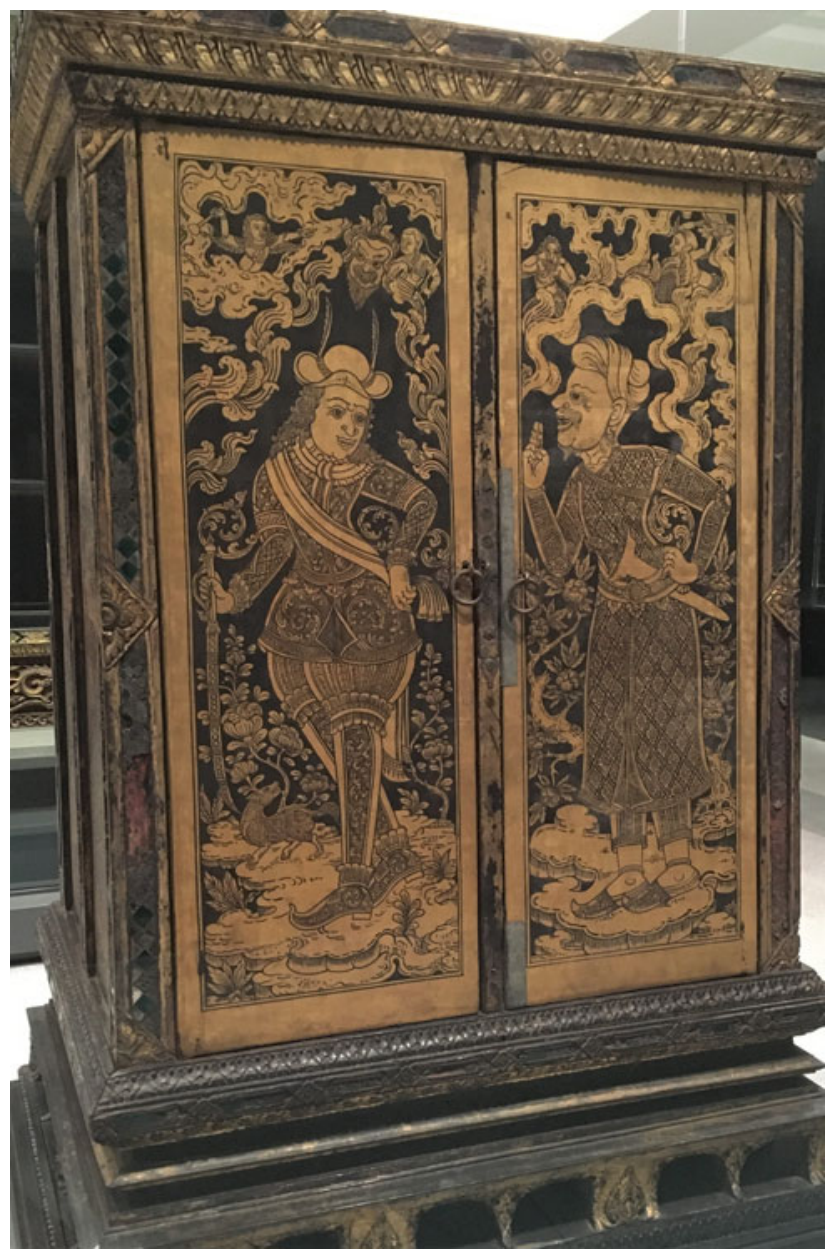

Figure 4. Lacquer manuscript cabinet featuring a European (left) and a Persian or IndoPersian (right), National Museum, Bangkok. Source: Matthew Reeder.

murals such as those at Wat Chaiyathit, Wat Suwannaram, and Wat Saket. ${ }^{67}$ Even some hill peoples such as the Karen-probably unfamiliar to the artists of the Ayutthaya period and virtually unknown outside the region before the 1820 -were, in the early nineteenth century, already associated with certain archetypal markers

${ }^{67}$ Jaiser, Thai Mural Painting, II: 65-71; Mural Paintings of Thailand Series: Wat Chaiyathid (Bangkok: Muang Boran, I99I), 23; Mural Paintings of Thailand Series: Wat Suwannaram (Bangkok: Muang Boran, I982), 52-3. 


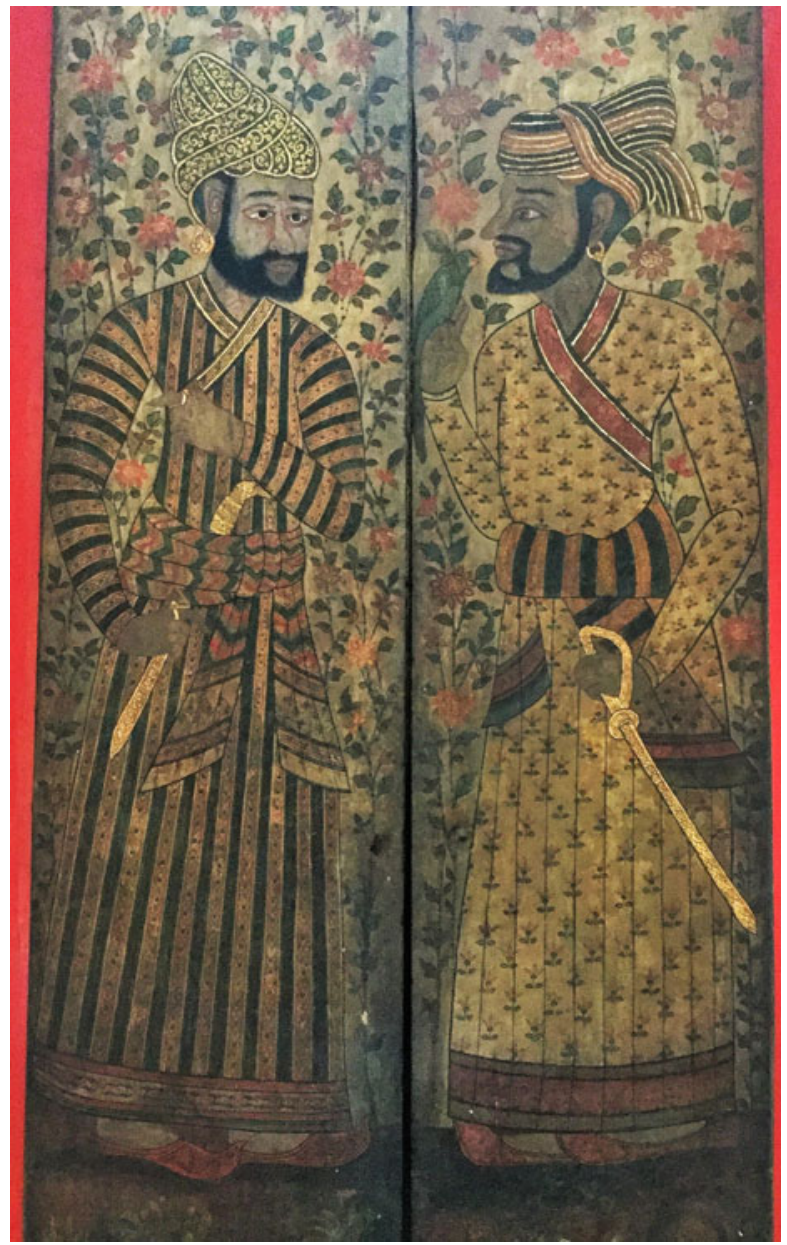

Figure 5. Portraits of Persians or Indo-Persians painted on the shutters of one of the directional viharas, Wat Pho. Source: Arthit Jiamrattanyoo.

of identification. ${ }^{68}$ A long off-white tunic with vertical stripes, a crossbow, and a woven basket distinguish Karen figures not only on the shutters at Wat Pho (Figure 6), but also in murals at Wat Bangkhae Yai and Wat Bang Yi Khan. ${ }^{69}$

${ }^{68}$ On the paucity of Ayutthaya-era evidence for the Karen, see Ronald D. Renard, 'Kariang: History of Karen-T'ai Relations from the Beginnings to I923' (PhD thesis, University of Hawaii at Manoa, I980), chapters 2-3.

${ }^{69}$ These are thought to date to the reigns of Rama II (I809-24) and Rama III (I824-5I), respectively. Mural Paintings of Thailand Series: Wat Bangkhae Yai (Bangkok: Muang Boran, I99I), 32-3. 


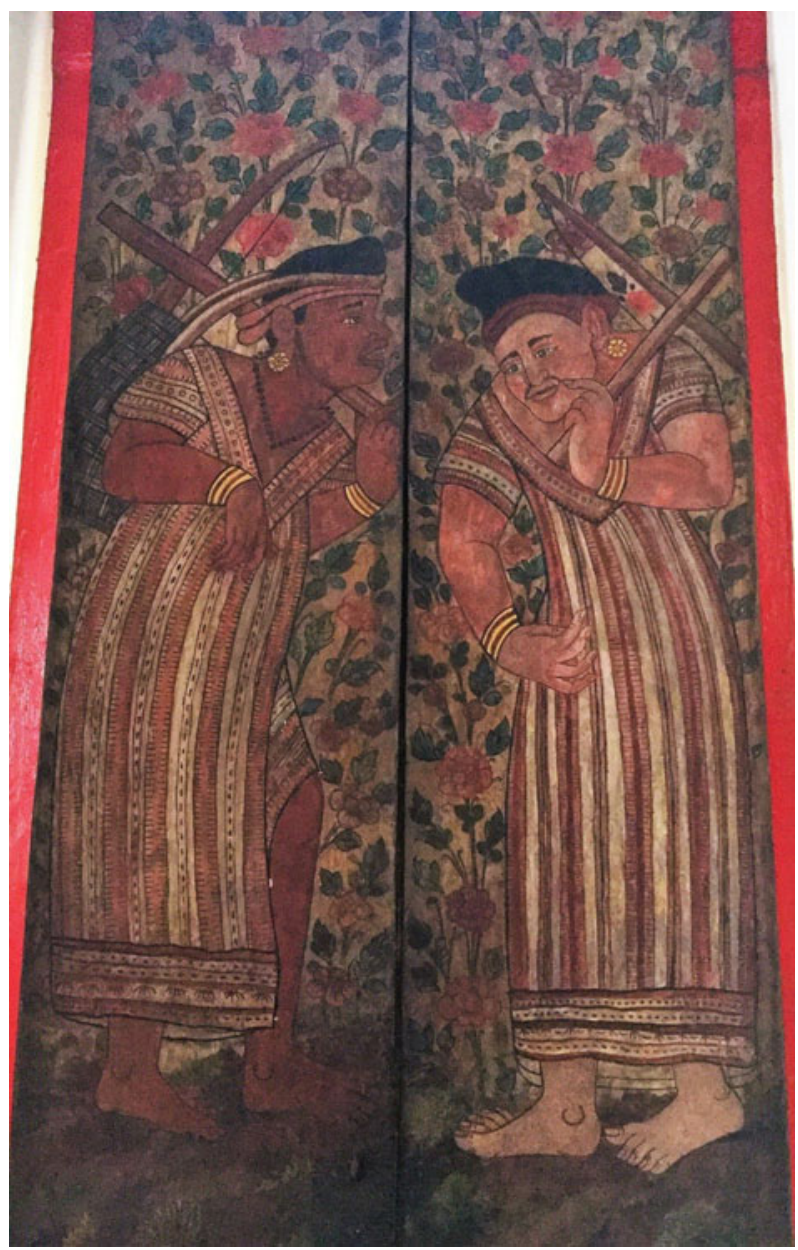

Figure 6. Portraits of Karens painted on the shutters of one of the directional viharas, Wat Pho. Source: Arthit Jiamrattanyoo.

The set of portraits at Wat Pho was not the only typology of peoples painted on the doors, shutters, and walls of important buildings in this period. ${ }^{70}$ In 1834 , a British envoy exploring trade opportunities, David Richardson, noticed a similar set of portraits at the palace of the king of Chiang Mai. He wrote:

${ }^{70}$ In addition to the two examples I mention here, guardian figures representing three or four different peoples and probably dating to the early or mid-nineteenth century can be found both at Wat Saket in Bangkok and Wat Phutthaisawan in Ayutthaya. On dating the murals at Wat Phutthaisawan, see Listopad, 'Art and Architecture', 342-50. 
The hall I was received in is a brick building about Ioo feet by 50, the walls painted with an extraordinary jumble of clouds, trees, temples, and on the window shutters natives of different countries in the act of salutation. Among others I observed two Europeans in the costume of the time of George II. ${ }^{71}$

Three decades later, a German doctor noticed portraits of various 'races' of Brahmins on the walls of Bangkok's Wat Suthat, which were probably painted in the Third Reign. ${ }^{72}$ In addition, the shutters of the ordination hall at Wat Bang Khun Thian Nok in Thonburi, which were also probably painted in the Third Reign, feature portraits of 22 different peoples in male-female pairs (Figure 7). As at Wat Pho, the portraits are not labelled, but the markers are familiar enough that all but one of them have been tentatively identified. ${ }^{73}$

Although the practice of posing foreigners as temple guardians dates to the Ayutthaya period, the nineteenth-century typologies at Wat Pho and Wat Bang Khun Thian Nok feature a larger selection of figures. By the I83os or I840s, full-length portraits of 20 different peoples or more graced the window shutters at both locations. Despite the availability of foreign illustrations and even the presence of actual foreigners, the artists eschewed empirical observation. Realistic likenesses were not the goal. Rather, by repeating the same tropes over and over, Bangkok's mid-century artists disseminated local conventions for categorizing the

${ }^{71}$ Richardson, Dr. Richardson's Missions, 8o. George II ruled Britain from I727 to I760. Sadly, this palace is no longer extant.

${ }^{72}$ The doctor, Adolf Bastian, comments that the portraits were accompanied by descriptive inscriptions, three of which he provides in translation. One states: 'This is the figure of a Phrahm [Brahmin] of the race Phi-Ramarath, deriving its origin from the town Ramarath. They wear the hair in a high pointed knot on the middle of the head, resembling the (pointed cap called) xadinmonxada, and then wind the cloth of a costly turban round it. They dress only in white garments to adorn themselves. They know the Sinlaprasat (magical or natural sciences), being expert in the Vethangkhasat-Pakon and the Xatxu-Vethasat, and use the Iswen-Mon (mantra of Siva) for the Vitthi-Sai. They observe different festivals, as for instance the Thavathot-Phitthi (the twelve monthly festivals of the year). They worship Phra-Inswen as the Lord, declaring him to excel in the world.' A. Bastian, 'Brahmanical Inscriptions in Buddhistic Temples in Siam', Fournal of the American Oriental Society 8 (1866): 378.

${ }^{73}$ Figures of about 22 different peoples are painted on the shutters of 14 windows, so most of the men and women paired together represent different peoples. Phanuphong Chongchua, 'Phap sipsong phasa thi ban natang ubosot wat bang khun thian nok' ['Painted Figures of I2 Nationalities on the Window Panels in Ubosoth Wat Bangkhunthien Nok'] (master's thesis, Silpakorn University, 2006). The phrase sipsong phasa ('I2 Nationalities') in the thesis title refers to an unspecific variety of peoples rather than the precise number I2. 


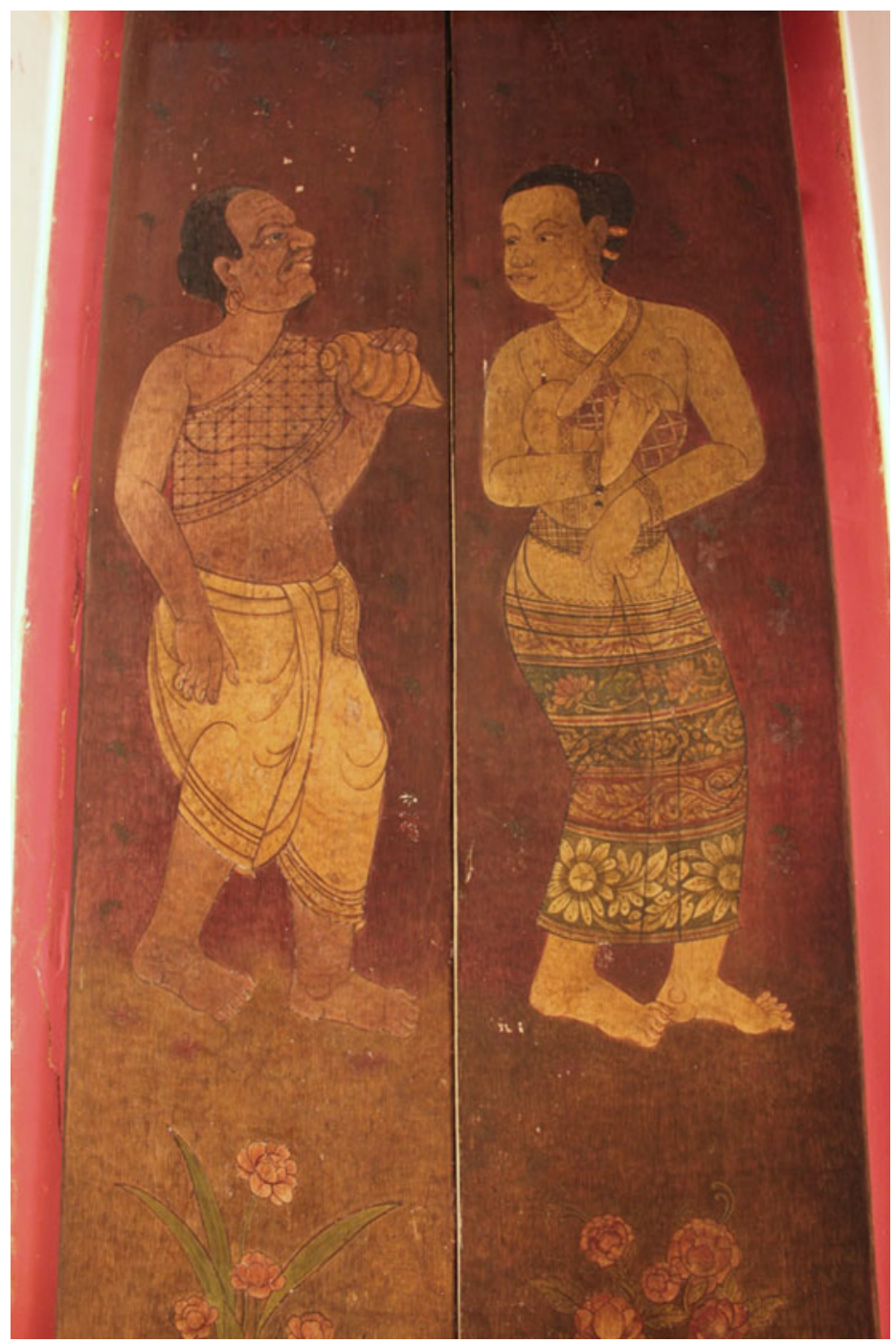

Figure 7. Recently restored portraits of a Brahmin man (left) and an unidentified woman (right), Wat Bang Khun Thian Nok, Thonburi, Thailand. Source: John S. F. Smith.

world's peoples. ${ }^{74}$ This was not unusual - in Europe, illustrations of the world's 'native' peoples also relied on the constant repetition of dated markers that rendered Europe's 'others' fixed in time. ${ }^{75}$ Artists in Siam

${ }^{74}$ Davisakd, Khon plaek na, I30-I; Peleggi, 'Turbaned', 6r.

${ }^{75}$ Noor, 'You Are Under Arrest', 203. 
likewise revived hoary tropes but, in the first half of the nineteenth century, they did so for a new purpose: to transform traditional depictions of foreigners as guardians into painted typologies offered up to facilitate comparison.

\section{The statues and the stanzas}

Representations of alterity took a different form in the string of $\mathrm{I} 6$ rectangular pavilions erected alongside Wat Pho's outer walls. At both ends of each pavilion, a small sculpture - approximately a metre high represented one of the world's peoples. ${ }^{76}$ On the walls behind the statues, mural scenes represented their characteristic 'fortresses or homelands'. ${ }^{77}$ Although no trace of the murals remains, a handful of the original 32 sculptures survive. ${ }^{78}$ In addition, each sculpture was accompanied by a two-stanza descriptive poem inscribed in stone on a nearby wall. Most of these inscriptions have likewise been effaced, but the poems themselves were recorded for posterity and have been published many times. ${ }^{79}$

${ }^{76}$ The locations of these pavilions, many of which were razed under King Chulalongkorn, are marked on a map in Phra Rajaveti, ed., Sathapat wat pho [Architecture of Wat Pho] (Bangkok: Wat Phra Chetuphon, 2009), 6r.

${ }^{77}$ Phra Si Wisutthiwong, ed., Sala phra thampanyabodi wat phra chetuphon (Bangkok: Amarin, 2003), 22.

${ }^{78}$ Peerapat Samran counts five remaining statues and identifies them as Ryukyuan, 'Shantou Chinese', Sinhalese, Chinese, and African - see Rajaveti, ed., Sathapat, I26. Photographs of the Ryukyuan and the 'Shantou Chinese' are published in Borannawatthu jak phra maha jedi 4 ratchakan: wat phra chetuphon wimonmangkhalaram [Old Things from the Stupas of Four Kings: Wat Phra Chetuphon] (Bangkok: Wat Phra Chetuphon, 1998), 71. Older photographs of the figure identified as a Ryukyuan are published in Rajaveti, ed., Sathapat, 328, and Prachum jaruek, I929 ed., between pp. 26 and 27. In the latter, however, the statue is labelled as an Arab, not a Ryukyuan. As of January 2020, the other three statues - Sinhalese, Chinese, and African - were stored in the Sala Phra Thampanyabodi building located alongside the monastery's north wall, near the bell tower. Photographs of these three figures can be found in Phra Si Wisutthiwong, ed., Sala phra thampanyabodi, I08. Since there are not separate verses describing a Chinese and a 'Shantou Chinese', it seems that one or more of these five statues have been misidentified.

${ }^{79}$ The 32 two-stanza poems can be found in Prachum jaruek, 2011 ed., 687-99; and Davisakd, Khon plaek na, 3 $3^{\mathrm{I}}-44$, with prose glosses on $\mathrm{I2}$ I-6. Winai reprints 29 of the poems with helpful annotations in his 'Jaruek wat phra chetuphon', I05-53. Confusingly, however, he links the verses to the shutter portraits discussed above, which 
Prince Paramanuchit Chinorot, the abbot of the monastery during the renovations, was heavily involved in the textual side of the project, compiling sources and composing inscriptions. In 1845 , he wrote a poem to celebrate the progress of the work. The poem includes a few lines about the statues of peoples and the inscriptions describing them:

Cast human figures of all the different peoples [phasa], Positioned at the ends of the verandas; beautifully formed, Two at each pavilion, with various appearances [phet], dear sir, Just like the [statues of] ascetics set up behind.

Khlong verses on display indicate the countries and name the peoples $[$ chat $]$,

Two stanzas [each] in elephant-foot meter. For all the lands,

Stone inscriptions on the walls declaring,

[their] many characteristics, with many lords; and specifying [their] lands. ${ }^{80}$

The statues and their poetic captions date to sometime between I834, when the encyclopaedic phase of the renovations began, and 1845 , the date of this commemorative poem. ${ }^{81}$

While the statues and verses, like the shutter paintings, cover an impressive number of peoples, they are not comprehensive. Some peoples who were known in mid-nineteenth-century Bangkok, such as the Portuguese, English, and Americans, were left out. ${ }^{82}$ At the same time, obscure peoples like Yipset-an and Sarakachuan were included. ${ }^{83}$ As

were in a different part of the monastery complex, rather than the sculptures they actually described. He discusses 93 ethnic terms found in this and other pre-modern Thai sources on pp. $5^{6-\text { Ioo. }}$

${ }^{80}$ Prachum jaruek, 201 I ed., 343-4, and, for a near-contemporary prose gloss, p. 66. Niyada Lausunthorn comments on these stanzas in Davisakd, Khon plaek na, 27-8.

${ }^{81}$ One of the pavilions that featured the statues and stanzas was constructed in I832-33. Phra Si Wisutthiwong, ed., Sala phra thampanyabodi, 22. According to Nidhi, Pen and Sail, I49, the composition of the verses describing the statues of peoples occurred in $183^{6-} 37$. This is possible, but he does not provide a source and I cannot confirm it. Santi Pakdeekham hypothesizes that they were composed between $183^{1-} 3^{2}$ and $1835^{-} 3^{6}$, but he cites a passage in Paramanuchit's poem that makes no mention of dating. See Phra Rajaveti, ed., Tamnak wasukri wat phra chetuphon wimon mangkhalaram [Tamnak Wasukri Residence at Wat Pho] (Bangkok: Wat Phra Chetuphon, 2016), $4^{8 .}$

${ }^{82}$ Prachum Faruek, i929 ed., 495.

${ }^{83}$ Tipset-an is usually assumed to mean Egyptians, although the clues in the poem itself - south of Java, just like the English - are puzzling. Winai suggests Gypsies. Sarakachuan is often thought to be Saracens or Circassians, but the poem suggests a 
with the social identification of peoples everywhere, the process was hardly scientific; Africans were lumped together as one, for example, while Russians were divided into the 'Petersburg Russians' and the 'Russians living near Chinese territory'. Likewise, separate statues and verses differentiated the figure of the 'Hindu', the 'Brahmin Hindu', and the 'Rammahet Brahmin'. ${ }^{84}$ Without exception, the stanzas and surviving statues use men as representatives of their peoples.

While each category of people is accorded equal attention - an identically sized statue and two stanzas - the poetic descriptions reveal the subjective, unsubtle judgements of the authors about the bodies and cultures of the peoples described. ${ }^{85}$ I will offer three examples: the contemptuous treatment of the African, the mockery of the Russian, and the glorification of the Thai. Each set of verses is signed by its author. I begin with the description of the African because it is the only one that can be linked with confidence to a surviving statue:

Head of chilis, frizzy and rough: Negrito [ngo] hair,

Grimacing, teeth bared, laughing; suitably dumb,

Living in the countries on the island of Africa,

An ignoble people [chot chat], with a complexion of black ink.

Pants striped with strings of flowers, a Surat pattern,

Wearing a white shirt, their favourite;

coastal people of India with sailing ships and Sepoy guards. Winai's proposal of Sarakhej seems closer to the mark. Winai, 'Jaruek', 98-9.

${ }^{84}$ By i863, according to Bastian, 'Brahmanical Inscriptions', 378, inscriptions at Wat Suthat assert that Rammahet was one of the four 'races' of Brahmins. At Wat Pho, because there are verses for both 'Hindus' and 'Brahmin Hindus', Winai suggests that the 'Hindu' refers not to the Hindu religion, but to the (Muslim) rulers of Hindustan. For a discussion of the possible referents for the various 'Russians' and 'Hindus', see Winai, 'Jaruek', 73-7. For a Romanized list of the $3^{2}$ peoples and the authors of each poem, see Terwiel, 'Mu'ang Thai and the World', 35 .

${ }^{85}$ Most of the verse inscriptions describing the statues of peoples had already been effaced when the texts of the Wat Pho inscriptions were first compiled for printing in the I920s. Prince Damrong and his assistants had to derive the text of the verses on peoples from copies of the captions in manuscript form. The printed volumes presumably follow the manuscript(s) in giving the glowing stanzas composed by Prince Paramanuchit on the Sinhalese and 'Siam' peoples first, followed by all the others, roughly clustered by culture or region but otherwise in no discernible order. I cannot determine whether viewers were intended to view the statues and stanzas in this order or not. On the compilation of the printed volume, see Prachum jaruek, I929 ed., 479, and Damrong's introduction to the same volume, ii-iii. 
A square cloth folded around the waist, Badly clothed, not a powerful look.

$$
\text { Ja Jitnukun }{ }^{86}
$$

Turning to the statue of the African (Figure 8), we can clearly see the curly hair and bared white teeth - markers of ugliness in mid-century Bangkok. The figure's trousers feature bold stripes that predate its recent restoration. No sign of the original floral pattern remains. ${ }^{87}$ The statue also appears to be lacking the cloth that, according to the poem, served as a belt. Nevertheless, the statue's hair, teeth, and striped trousers suggest that the African's sculptor and his poet attempted to call attention to the same tropes.

The poetic description of the Rut Pita-sabak combines the author's negative judgement of the Russians of St Petersburg with information that must have been adduced from a foreign interlocutor or gazetteer:

The figure of the Petersburg Russian, of the lands of the west, sir, Their country is populous, so I have heard.

In the wet season, hail falls, And frigid winds hurl down rain.

The countryfolk there wear coats of sheepskin, And sleep close to the fire.

Some skin goats and wrap themselves up:

Infused with stench and reeking of odour.

In these lines, markers of identification include the geographical location of the Russian homeland, its extreme weather, a vague second-hand notion of

${ }^{86}$ Winai, 'Jaruek', I5I. I use Negrito for the Thai word $n g o$, which has a double meaning. First, it refers to Negrito people - specifically the people living on the Malay Peninsula who call themselves Mani. Although the Ngo did not have their own statue at Wat Pho, they figured memorably in Sang Thong, a drama composed by King Rama II. Second, $n g o$ is the word for the rambutan fruit. Both the hair of the Negrito and the hair of the fruit are curly, which is the imagery intended in this line of the poem.

${ }^{87}$ By the end of the twentieth century, the surviving statues were badly damaged. Their extremities were missing and most of their paint was gone. The two figures featured in photographs in Borannawatthu, 7I, published in 1998, appear to have been recently repainted. Photographs published in 2003 show a craftsperson restoring the limbs of the three other statues - including the African - with concrete. Phra Si Wisutthiwong, ed., Sala phra thampanyabodi, Io8.

${ }^{88}$ I have modified the translation in Dhani, 'Inscriptions', I63. For the Thai version, see Winai, 'Jaruek', I39. 


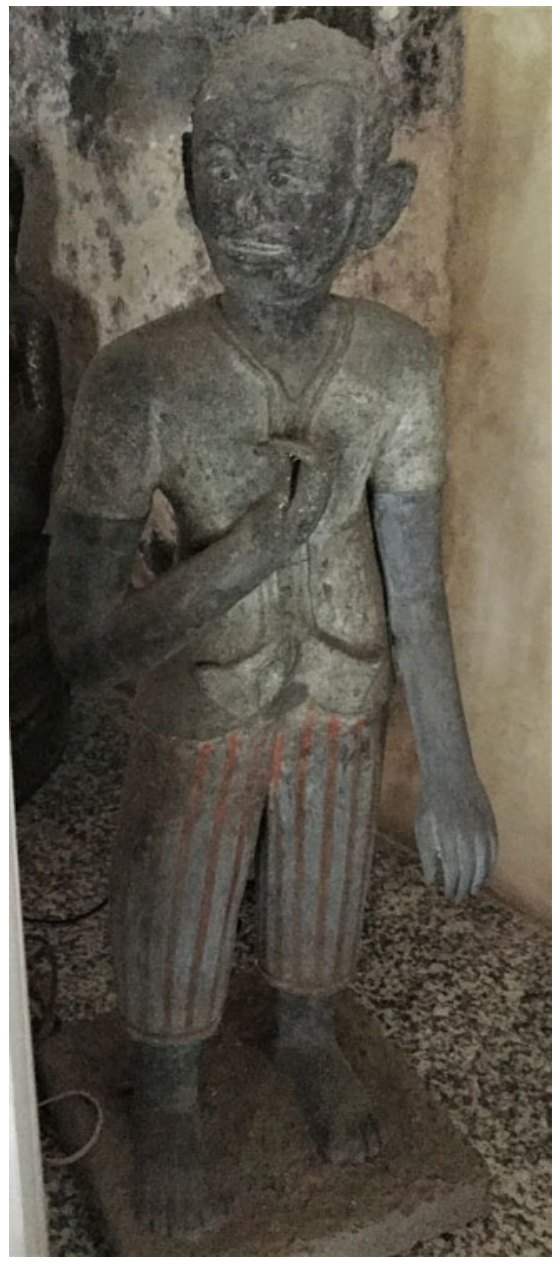

Figure 8. Sculpture of an African, Wat Pho. Source: Arthit Jiamrattanyoo.

Russia's large population, a description of the hearths and coats of its rural people, and a derisive comment on their odour. The scholar Barend Jan Terwiel has argued that entertainment was more important than accuracy in these verse descriptions of peoples, but it was not unusual for early ethnographic descriptions worldwide to focus on the unusual, the comic, and the disgusting. ${ }^{89}$ After all, memorable features aided differentiation. I have not been able to trace the source of this information on the

${ }^{89}$ Terwiel, 'Mu'ang Thai and the World', 27. 
Russians, but the details and the qualitative judgements were characteristic of both English and Chinese gazetteers of the period. ${ }^{90}$

Other figures are described with admiration, but the most flattering verses were reserved for the statue of the 'Siam[ese]' ${ }^{91}$ Along with the Sinhalese people, who were the highly respected inhabitants of the great Buddhist 'continent' of Lanka, the stanzas on the 'Siamese' were composed by the temple's abbot, Prince Paramanuchit, himself. The prince was considered old-fashioned in both his beliefs and his writing style. ${ }^{92}$ He joined his teacher, Phra Phonnarat, and his nephew, King Mongkut, in preferring 'Siam' over the colloquial 'Thai' to label his own language, kingdom, and people. In fact, throughout his life, the prince remained unusually reluctant to use colloquial labels for peoples in his verse compositions, preserving the style of a bygone era in which such labels had little role in formal expression. Of the 'Siamese', he writes:

The figure of the Siam[ese], handsomely dressed as if by angels,

In the royal city, built and protected, prosperous and mighty.

The nobleman of Ayutthaya, look how great he is, sir!

Exuding power; throughout the lands, all tremble.

Donning a beautiful silk shirt with gold and silver threads,

Patterned silk wrapped at the waist, snug and dashing,

From head to toe, his body made up splendidly,

Displayed at the temple of the Buddha, full of beauty.

Krommamuen Nuchit Chinorot ${ }^{93}$

The decision to include a figure representing the 'selves' of the Bangkok elite - or, at least, most of them - marks a shift in classificatory thinking. The term 'Thai' was rarely used as an ethnic label before the late eighteenth century and 'Siam[ese]' was even rarer. And, in contrast

${ }^{90}$ In a diary entry dated 3I December I836, Dan Beach Bradley writes that the abbot of the Phra Khlang's monastery (Wat Prayunwongsawat) had kept him up all night translating a history of Russia, but it is not known what text this was, or whether the abbot shared his information with the writer of the stanzas. D. B. Bradley, Abstract of the Fournal, 37; Davisakd, Khon plaek na, I20.

91 The Japanese were also described with esteem. See Dhani, 'Inscriptions', i62-3.

${ }^{92}$ Nidhi, Pen and Sail, 23, 218-20, 257, 301.

${ }^{93}$ Krommamuen Nuchit Chinorot was Paramanuchit's title before he was appointed patriarch in 185I. See also the partial translations of these verses by Dhani, 'Inscriptions', I6I-2, and Chris Baker and Pasuk Phongpaichit, A History of Thailand (Cambridge: Cambridge University Press, 2005), 62. For the Thai text, see Winai, 'Jaruek', I4I. 
with the African, the Petersburg Russian, and most of the other figures, the Siamese was represented by a nobleman, not a commoner. The inclusion among the statues of a 'Siamese' nobleman suggests that, by the mid-nineteenth century, Bangkok's writers believed that they constituted a people, too; ethnic labels were not just for 'others'. ${ }^{94}$

The verses shift easily between references and referents. The verses are associated with the statue, the statue with the nobility, the nobility with the 'Siamese', and the Siamese with the royal city. The name of the old capital, Ayutthaya, is also applied to Bangkok, suggesting the continuity of Siam's ruling classes over time. The verses helped readers to make the association between the statue in front of them, the officials of the state, and the representation of the Siamese. Most Thai commoners, however, would have seen little of themselves in either the stanzas or the statue.

As the historian Davisakd Puaksom has observed, the markers of identification used in the verses vary substantially. Descriptions of all but two of the sculptures call attention to the people's dress. Most of the poems allude to the people's homeland or associate them (usually vaguely) with a kingdom or polity. About half make some mention of the people's beliefs or religious practices and about a third refer to their typical occupations or skills. Nine of the descriptions mention skin colour, facial features, or beards. ${ }^{95}$ As with the shutter paintings, the sculptors and poets often highlighted the characteristics that marked difference most memorably. Many of these markers were exaggerated or dated. Few of Bangkok's diverse foreign residents looked much like their representatives in sculpture and verse. It would be misleading to conclude that any one kind of marker was used to define peoples in mid-nineteenth-century Bangkok, as the verses use so many. It might appear from the use of the word phasa (lit. 'language') to label categories of peoples - as in the commemorative poem by Paramanuchit quoted above - that native language was the deciding factor. In the verses, however, language characteristics were largely ignored.

Responsibility for the composition of the $3^{2}$ poems was parcelled out to I8 different writers. They ranged from princes to lower-ranked monks and

${ }^{94}$ On the transition toward using ethnic labels - especially 'Thai' - in Thai-language chronicles, see Matthew Reeder, 'Royal Brother, Ethnic Other: Politicizing Ethnonyms in the Chronicle Compositions of Early Bangkok', Rian Thai: International Journal of Thai Studies Io, no. 2 (2017): 65-99.

${ }^{95}$ Davisakd, Khon plaek na, 127-37. 
officials about whom we have only fragmentary information. It was appropriate that Paramanuchit, an abbot and future patriarch, wrote about the Sinhalese people of the celebrated Buddhist land of Lanka and that Luang Likhitpricha, who had led a corps of scribes to Battambang with Bangkok's army, wrote about the Khom (Khmer). ${ }^{96}$ Otherwise, it appears that writers were not chosen for their familiarity with the peoples they described, but because of their skills at verse composition. In fact, most of these authors worked on multiple texts for Wat Pho. In addition to describing the statues of peoples, four of them also composed verse captions for murals of Ramayana scenes, ten of them also contributed stanzas describing the exercises of ascetics, and five also supplied stanzas for a set of verses exemplifying prosody. ${ }^{97}$ It has been assumed that the authors were partisans of the king, but this was not strictly the case. ${ }^{98}$ Many of the authors were too lowly to have left us much evidence about their connections, while two of the more exalted authors - Paramanuchit and Dechadison - are known to have been close to Mongkut, as well.

Dechadison, the head of the palace scribal corps, also appears in the diary of the American missionary, Dan Beach Bradley. In I840, according to Bradley, news of the outbreak of the Opium War prompted the royal court to question the relative power of China, Britain, and other states. Dechadison first sought the advice of the Catholic bishop, Jean-Baptiste Pallegoix, who naturally identified Rome, along with England and Russia, as the 'greatest kingdoms on the earth'. The prince then invited Bradley to comment, in the American's words, on 'the different races of men now living on the face of the earth, their manners and customs, and the extent of their territories'. With several missionary colleagues, Bradley took some time to compile a table that

${ }^{96}$ On Likhitpricha, see 'Jotmaihet kiaokap khamen lae yuan nai ratchakan thi sam' ['Records on Cambodia and Vietnam in the Third Reign'], in Prachum phongsawadan chabap kancanaphisek [History Series, Kanjanaphisek Edition], vol. I2 (Bangkok: Fine Arts Department, 2006), 705. Several of the authors appear to have been officials at the court of the late Front Palace prince.

97 The king himself made contributions to the latter two works. Prachum jaruek, 201 I ed., ${ }_{476-515}{ }^{1}, 554,704-83$. See pp. 368-9 for Paramanuchit's short essay in rai verse attributing authorship for most of the inscriptions. The verses on ascetics were ordered in 1836 and finished in I838-39- see A. B. Griswold, 'The Rishis of Wat Pó', in Felicitation Volumes of Southeast-Asian Studies Presented to His Highness Prince Dhaninivat, vol. 2 (Bangkok: Siam Society, I965), 321.

${ }^{98}$ On the poets as partisans of the king, see Winai, 'Jaruek', 43; and Sujit Wongthet (in Davisakd, Khon plaek na, xv-xvi). 
ranked I5 European nations and included statistics about their populations, territories, and military forces. Rome was ranked last. The prince did not accept the information uncritically - he was sceptical that the missionaries could get reliable statistical information and he rightly suspected that Protestants and Catholics were biased in favour of their own coreligionists. ${ }^{99}$ Indeed, it is likely that he knew more than he let on. ${ }^{100}$ Despite Dechadison's interest in ranking nations, comparing statistics, and seeking knowledge from foreigners, there is no evidence that this information informed any of his verse descriptions of peoples. Dechadison himself did not write about Europeans at all, but about the Chinese, Japanese, Koreans, and Sarakachuan.

However, some sources of information can be inferred. The names of almost two-thirds of the peoples described in the poems at Wat Pho can be found in a list of 62 peoples embedded in Nang Nopphamat - a multi-author treatise from the late I820s or early i83os. Even the names of a few obscure peoples like the Rammahet Brahmins are found in both compositions, so the list in Nang Nopphamat may have been one of the sources consulted. ${ }^{101}$ Evidence in the stanzas themselves suggests that local knowledge about peoples was supplemented with foreign sources of information. Even the names of some of the peoples were probably unknown before the nineteenth century. In all other pre-modern sources, the Thai-language term for the Dutch was Wilanda, probably derived from the Portuguese and Malay term for Holland. Yet, one of the poems describes a statue of a Dotchi, who is said to hail from a land adjacent to Wilanda. Scholars usually assume that Dotchi is the Thai version of the English word for the Dutch, but it seems more likely that it comes from the Dutch or German word for Germans. ${ }^{102}$ In any case, the word was new to Siam. The verses on the French and the Sarakachuan claimed that each used Sepoy soldiers. Sepoys were

${ }^{99}$ D. B. Bradley, Abstract of the Fournal, 68-7r; Terwiel, 'Mu'ang Thai and the World', $22-3$.

${ }^{100}$ As early as 1829, a French priest remarked that, although many in Bangkok 'fail to distinguish between Christians [i.e., Catholics] and the English; others are reasonably aware of the different European states. I was surprised to hear Malay, Siamese, and Chinese speak about France, the revolution, Bonaparte and some aspects of his life in some detail'. Bruguière, 'Description of Siam', I26.

${ }^{101}$ Or, perhaps, both compositions shared the same authors or sources. Nidhi, Pen and Sail, 244-5; Winai, 'Jaruek', 52-4; Sujit Wongthet, ed., Mai mi nang nopphamat mai mi loi krathong samai sukhothai [There Was no Nang Nopphamat and no Loi Krathong in the Sukhothai Period] (Bangkok: Matichon, 2002), I7.

${ }^{102}$ Winai, 'Jaruek', 76. 
probably not well known in Siam before Crawfurd's contingent of Sepoy guards caught the attention of the royal court. ${ }^{103}$ One set of stanzas associates the Qing with Tartars (Tat), explicitly positioning the imperial family as outsiders who compelled the 'Chinese' to start wearing queues. The persistent differentiation of the Manchus from the Chinese was common in accounts from East Asia. ${ }^{104}$ Finally, the poem on the Muslim Hui people of China admits that no one knew what they looked like and that the sculptor had to base the statue on hearsay.

The inclusion of vocabulary and information from a variety of foreign sources - both Chinese, it seems, and European - shows that the statues and stanzas did not simply reproduce 'traditional' knowledge. At the same time, like the shutter portraits, they revived many well-worn tropes. In other words, Wat Pho's portraits, statues, and poems represent something quietly innovative: an effort to reconcile new sources of information and new comparative formats with old social categories and markers of identification. The poets juxtaposed the intimately known Siamese with the unfamiliar Russians, and the well-worn tropes of European hats and wigs with hearsay about the Hui. The knowledge about the peoples of the world produced for display at Wat Pho was not intended to represent Siam's 'traditional' knowledge. Rather, it was part of a grand project to demonstrate local command of a universal body of knowledge. As such, it combined information and forms of expression from both foreign and local sources, copying neither wholesale.

\section{Defining peoples for Bradley's dictionary}

Dictionary definitions, like the artistic depictions and poetic descriptions of peoples, relied on tropes and archetypes. Nowhere were these definitions so expressive as in the monolingual Thai-Thai dictionary produced under the direction of the Protestant missionary, Dan Beach Bradley, in the early i850s. ${ }^{105}$ The dictionary provides entries for at least 20 different peoples, or more than 40 if subentries are counted separately. Because the dictionary is associated so closely with its American originator, it has not been considered in the context of local knowledge production. It is true that Bradley dictated the

${ }^{103}$ Crawfurd, Fournal of an Embassy, I: I39.

${ }^{104}$ Toby, 'Imagining and Imaging', 32.

${ }^{105}$ D. B. Bradley, Nangsue akkharaphithansap: Dictionary of the Siamese Language (Bangkok: I873; reprint, Bangkok, Khurusapha, I97I). 
format of the dictionary in at least two respects: even the simplest words were given definitions and entries were arranged alphabetically. ${ }^{106} \mathrm{It}$ appears that he also compiled the list of words to be defined. The definitions, however, were composed by Bradley's 'language teachers' - native speakers educated in the Buddhist tradition - and they reflect a local perspective. In format, early missionary dictionaries such as Bradley's increasingly resembled the user-friendly lexicons that local scholars had begun producing in response to a late eighteenth- and early nineteenth-century trend towards reading for pleasure. So, to the Bangkok literati of the time, the monolingual dictionary produced by Bradley's teachers appeared innovative, both in form and in content, but not alien. I make this case in the pages that follow before examining the dictionary definitions themselves.

Compared to other dictionaries compiled in the mid-nineteenth century, Bradley's was an impressive feat. It contains five times as many entries as its only monolingual precursor - a dictionary manuscript also compiled by 'native assistants' under the direction of the missionary Jesse Caswell - and its definitions are longer and more expressive. As such, it offers the richest evidence of local efforts to identify and define the peoples of the world. Although Bradley began collecting words for a monolingual dictionary in 1838 , the work lapsed at some point before he embarked on a three-year trip to America in $1847 .{ }^{107}$ In I85I, shortly after Bradley's return, Mongkut succeeded Rama III and Bradley's old teacher, Ajan That, offered to restart his work. Bradley wrote of visiting 'the monastery of Teacher That', so it seems that Ajan That was closely associated with a monastery_-perhaps as a lay leader or a former monk. ${ }^{108}$

In a September I854 diary entry, Bradley notes his dissatisfaction with his previous efforts to produce a monolingual dictionary and explains how he restarted the project in $\mathrm{i} 85 \mathrm{I}$ :

106 Technically, the Thai writing system is not an alphabet, but a syllablebased abugida.

107 Theraphan L. Thongkum and Pranee Kullavanijaya, 'Lexicography of the Thai Language', in Dictionaries: An International Encyclopedia of Lexicography, ed. Franz Josef Hausmann et al., vol. 3 (Berlin: Walter de Gruyter, I991), 2578.

${ }^{108}$ An atmosphere of suspicion against Europeans and Americans pervaded the final years of the Third Reign. Bradley's language teachers avoided him until after Mongkut's accession. Theraphan L. Thongkum, Kantham photjananukrom thai-thai: adit-patjuban (pho. so. 2389-2533) [The Making of Thai-Thai Dictionaries, Past to Present (I846199o)] (Bangkok, Chulalongkorn University, I99i), 53-4. 
I judged it best to have a new more perfect arrangement made comprising if possible nearly if not quite all Siamese words in the language. Hence I set my Siamese teacher, a fine scholar, at the work, overseeing and directing him in it. He has now had that work in hand nearly four years defining all the words himself alone. Within the last year I have called in my old teacher Nai Muang to take a part in the work in order that it may be the sooner brought to a close. ${ }^{109}$

Definitions were finally completed in May i855. The dictionary, Bradley wrote, was 'wholly Siamese and the words have been defined wholly by Siamese scholars under my own particular supervision'. ${ }^{10}$ Although his second teacher, Nai Muang, evidently assisted, a note printed on the first page of the dictionary credits Ajan That with the definitions. At 40,000 words, it was the most comprehensive Thai dictionary to date. Although it is possible that Bradley made some modifications here and there, there is no evidence of major revisions or additions. ${ }^{111} \mathrm{On}$ the contrary, many definitions reflect a distinctly local perspective. In manuscript form, Bradley's dictionary had few readers, but the composition nevertheless reveals the kind of knowledge circulating in mid-century Bangkok. ${ }^{112}$

The form of the dictionary-comprehensive and practicalcorresponded with trends in Thai readership in the late eighteenth and early nineteenth centuries. In the old kingdom of Ayutthaya, literature was usually recited and heard, not read. Treatises on Thai prosody, such as the series of related texts called findamani, were designed to assist composition, not consumption. Older versions of findamani included a lexicon of difficult words arranged homophonically to help writers to distinguish words that sounded alike and to spell them correctly. Many of the words in these lexicons were not, however, defined or provided with synonyms. ${ }^{113}$ In the early nineteenth century, as Nidhi Eoseewong has argued, a trend among elites toward reading for pleasure was well underway. Primers for teaching basic reading skills

${ }^{109}$ D. B. Bradley, Abstract of the Fournal, I73; Theraphan, Kantham photjananukrom, 54 .

${ }^{110}$ D. B. Bradley, Abstract of the Fournal, I83; Theraphan, Kantham photjananukrom, 55.

${ }^{111} \mathrm{He}$ may have taken some time to 'review, correct, and enlarge' the dictionary, as he wrote that he would do in 1855 . He declared it ready for printing in I86I, though it was not actually printed until 1873 , the year of his death. Theraphan, Kantham photjananukrom, $5^{\mathrm{O}}-5$.

${ }^{112}$ After it was printed in 1873 , the dictionary became influential. The government's first official dictionary, published in I89I, used it as a major source. Theraphan and Pranee, 'Lexicography', 2579.

${ }^{113}$ Peera Panarut, 'Cindamani - the Odd Content Version: A Critical Edition' (master's thesis, University of Hamburg, 2015), I5-27, 38; Nidhi, Pen and Sail, I60-I. 
proliferated. A new edition of Findamani featured a lexicon in which the words were rearranged topically (although still in a rather stream-of-consciousness fashion) and assigned brief glosses. ${ }^{114}$

Another lexicon, the Kham Ritsadi, was probably written in the early I85os. Dechadison was its author, likely in collaboration with Paramanuchit and another prince. ${ }^{115}$ This new work improved on earlier lexicons by expanding the number of entries considerably, to around I,30o, although they were still limited to difficult words with obscure roots. The work's topical organization was a bit more intuitive than previous lexicons and, in addition to assigning synonyms or brief definitions for every entry, examples from literary or colloquial sources were provided for some words as well. One topical cluster in the Kham Ritsadi defines nine rarely used labels for peoples. Meng, for example, is defined as Mon. The word Man, defined as Phama (Burmese), is supplemented by what seems to be an obscure saying: 'Man trade crows; Khula trade chickens. ${ }^{116}$ It is tempting to wonder whether Dechadison was inspired to embark on this project after having a conversation with Bradley in I840. The missionary, who had already envisioned writing dictionaries himself, proposed to the prince that 'some efforts' be made to 'settle the language upon some standard, as [with] dictionaries and grammars'. In reply, according to Bradley, 'the prince very modestly confessed that the Siamese grammar was a confused thing and quite beyond his depth'.

In the end, just like the missionary dictionaries, the Kham Ritsadi was designed as a reference work for learners and readers. According to the colophon on one surviving manuscript, its purpose was 'to enable women and men who love learning about works of kap, khlong, lilit, and chan [verse forms] to understand and remember ... [it is] much like an aphithansap'. ${ }^{118}$ The reference to an aphithansap would have brought to

${ }^{114}$ Nidhi, Pen and Sail, г02-3, I27-31; Peera, 'Cindamani', 38.

${ }^{115}$ Prince Paramanuchit Chinorot et al., Kham Ritsadi (Bangkok: Wat Phra Chetuphon, 20Io). The colophon of the manuscript reproduced in this book (p. 3) gives the names of all three princes. However, another manuscript copy lists Dechadison as the sole author and notes that a later editor filled in some gaps (see Theraphan, Kantham photjananukrom, 30). If the titles of the author(s) in the colophons were current at the time of composition, the Kham Ritsadi was produced after 1851. Paramanuchit died in I853, Dechadison in I859.

${ }^{116}$ Paramanuchit et al., Kham Ritsadi, 55 .

${ }^{117}$ Even earlier, in I839, Bradley wrote that Dechadison was 'considered one of the best Siamese scholars in the country'. D. B. Bradley, Abstract of the Fournal, 6o, 70.

${ }^{118}$ Paramanuchit et al., Kham Ritsadi, 3. While the colophon compares the Kham Ritsadi to an aphithansap, the lexicon in the Findamani texts was often called a nammasap. See Peera, 
mind, at least for locals with a monastic education, the expansive twelfth-century Pali lexicon called the Abhidhānappadīpikāa, known throughout the Theravada world. ${ }^{119}$ Bradley's dictionary sported a similar title, Akkharaphithansap, which was likewise a deliberate attempt to situate the work into a locally recognizable genre. ${ }^{120}$ To well-read locals, Bradley's dictionary would have appeared innovative, but not completely foreign. Like the Kham Ritsadi and the other new user-friendly lexicons, its format addressed the needs of an increasing number of Thai readers.

In Caswell's dictionary, the definitions of the names of peoples are generally limited to stating, vaguely, that they refer to a people. Sometimes, the direction of the people's homeland from the vantage point of Bangkok is also mentioned. ${ }^{121}$ Fortunately, most of the definitions in Bradley's dictionary are more expansive. The authors, Ajan That and Nai Muang, were rarely content to say that a word was merely the name of a category of people. They usually added other details, such as synonymic labels, geographical origins, and markers that, they implied, distinguished one people from another. The sort of markers invoked in these definitions varied considerably, but clothing and hairstyle were most common. In addition, the definitions indicate that labels for peoples were, by the mid-nineteenth century, conceived of as referring to bounded, coherent groups and that the abstract term for such groups was still in flux. The words phasa, chat, and phuak - each word carrying its own connotations-were

'Cindamani', 23. On a different copy of the Kham Ritsadi text, the scribe describes the intended audience as youthful learners ('dear noble children [kunlabut]' rather than 'women and men who love learning') and describes it as a resource 'for looking up words [thi khon sap]'. Theraphan, Kantham photjananukrom, 30.

${ }^{119}$ A printed version of the Pali text, to which Sinhala and English glosses have been added, is Moggallāna Thero, Abhidhānappadīpikā; or, Dictionary of the Pali Language, by Moggallāna Thero, with English and Singhalese Interpretations, Notes, and Appendices, ed. Waskaduwe Subhūti (Colombo: W. Henry Herbert, I865). Some Buddhist manuscript collections in the region include the Abhidhānappadīpikā and commentaries. See, for example, Peter Skilling and Santi Pakdeekham, eds., Pāli Literature Transmitted in Central Siam: A Catalogue Based on the Sap Songkhro (Bangkok: Fragile Palm Leaves Foundation, 2002), $242^{-}-3,256$.

120 The way in which Bradley's writers understood the dictionary's title is suggested by their definition for the word aphithan-akkhara: 'a treatise [organized by] the initial letters of words.' D. B. Bradley, Nangsue akkharaphithansap, 795.

121 'Khmer', a typical example, is defined simply as 'the name of a people who live to the east'. J. Caswell, A Dictionary of the Siamese Language by 7. Caswell, Copied and Enlarged by 7. H. Chandler (Bangkok: Chulalongkorn University Press, 200I), 75. 
used interchangeably to refer to what today we might call an 'ethnic group'.

Four example definitions illustrate the variety of markers and abstract terms used by Ajan That and Nai Muang:

Lawa, are the people of one phasa called Lawa. People of this phasa have no mueang [town, state]; they have only villages. They wander and reside in the mueang of a king.

Kaew, are the people of one chat; [they are] as if from a Lao mother and a Vietnamese father.

Phama [Burmese], is the name of people in Ava. People of that mueang generally keep their hair long, and put it up high on their heads.

Fek [Chinese], [are] Fin [Chinese]; [they] are a phuak of people who keep their hair long in braids [queues], wear shirts and pants, and come from China. ${ }^{123}$

Types of markers mentioned in these four definitions include clothing, hairstyles, origins, locations of residence, forms of settlement, and comparisons to other groups. Identifying markers found in other entries also include tattooing practices, skin colour, and body size.

The markers in the definition for $\mathcal{J} e k$ - a colloquial term for Chinese that later become derogatory - are particularly revealing in two ways. First, they remind us that some of these markers could be manipulated, both by the state and by individuals. In nineteenth-century Bangkok, the queue (or pigtail) was one of the state's primary means of identifying its male Chinese subjects. As Chinese and Thai subjects were treated very differently by law-regarding taxation, corvée, conscription, marriage, mobility, and so on - it was not uncommon for Chinese subjects to cut off their queues and join another category. Similarly, when opium was legalized for Chinese in $185 \mathrm{I}$, the state permitted non-Chinese to continue their habit, but only if they re-registered as Chinese and grew queues. ${ }^{124}$ Second, the definition reflects the subjective perspective of the people who wrote it. Shirts and

${ }^{122}$ While phuak simply referred to a group, the use of phasa implied that peoples were formed on the basis of the 'language' they spoke, and chat implied that peoples were social categories determined by collective karma.

${ }^{123}$ D. B. Bradley, Nangsue akkharaphithansap, 6I8, 43, 452, I4I. In addition to the entry for fek, there were also entries for other terms referring to Chinese, including fin and fin- $\mathrm{Ho}$.

${ }^{124}$ Colloquially, they were called 'fake Chinese'. Kasian Tejapira, 'Pigtail: A Prehistory of Chineseness in Siam', Sojourn 7, no. I (I992): 95-I22. 
pants only make effective markers of difference in a context in which most people - like Ajan That and Nai Muang - did not wear such clothing. It is unlikely that Bradley, who invariably dressed in shirts and pants, would have crafted such a definition.

Like the shutter paintings, the statues, and the verses, Bradley's dictionary formatted knowledge in an unprecedentedly systematic fashion. Although it drew on Western prototypes, its format complemented recent advances in lexicons compiled by local literati, which were also becoming more comprehensive and reader-oriented. In contrast to the Kham Ritsadi and the lexicons in the Findamani texts, however, it included even the most common words familiar to every Thai speaker. The names of each people, from small hill tribes to the 'Thai' themselves, occupied an entry just like every other, arranged objectively in alphabetical order. The list of words defined in the dictionary were collected from Thai-language texts, not foreign ones, so there were no entries for the distant or obscure peoples featured at Wat Pho like the Sarakachuan and the Petersburg Russians. Bradley's dictionary was written by local scholars whose definitions reflected local understandings of what distinguished peoples from one another. The markers of difference cited in the definitions - such as clothing, hair, and homeland-were subjective in that they defined peoples, in one way or another, as others. Only the Thai were spared an association with such markers. Bradley's dictionary relates simply that they are the people of Bangkok; Caswell's says that they are from 'here'. ${ }^{125}$ As a resource for knowledge about the peoples of the world, Bradley's monolingual dictionary integrated local markers, perspectives, and labels into a new, more systematic organization.

\section{Conclusion: constituting and comparing peoples}

Two generations after the renovation of Wat Pho and the composition of Bradley's dictionary, Siam's intellectuals joined their peers elsewhere in Asia in embracing a new global trend in the organization of knowledge about the world's peoples. European Orientalists had begun to evaluate peoples on a temporal yardstick of civilization as early as the eighteenth

${ }^{125}$ Caswell, Dictionary, 365; D. B. Bradley, Nangsue akkharaphithansap, 287. Both dictionaries note that another meaning of the word thai was the condition of being 'free' commoners (as opposed to slaves). 
century, positioning 'primitive' tribes on one end and 'advanced' civilizations on the other. Not only were peoples assessed qualitatively as before, but they were mapped onto a timeline of progress and, despite their contemporaneous coexistence, associated with different eras of development. ${ }^{126}$ This trend spread steadily. By the middle of the nineteenth century, Ottoman elites were internalizing these lessons, adapting them, and incorporating them into descriptions of peoples in their own empire. ${ }^{127}$ Officials in China, long used to assessing peoples' civilizational attainment, were moved by Darwinian theories of race and, by the turn of the twentieth century, used them to reframe their own imperial self-representations and historical narratives. ${ }^{128}$ Siam's officials were not immune to this global shift in classifying peoples. Officials under King Chulalongkorn (r. I868-1910) and his successors began to identify peoples inside and outside their kingdom and assign them places on a temporal scale of progress as well. ${ }^{129}$

While Siam's turn of the twentieth-century intellectuals were inspired by global intellectual trends, they built on the conceptual innovations of the mid-nineteenth century. These innovations are reflected in the systematic and comparative formatting of the visual and textual studies of alterity discussed in this article. In multiple forms of expressionfrom the paintings and sculptures to the verses and definitionsarchetypal representations of dozens of peoples were offered up on equal terms. The statues, just like the shutter portraits, were all the same size. Precisely two stanzas of verse described each statue. Each dictionary entry was sorted alphabetically. Unlike most prior visual or textual representations of peoples, these mid-century works showed peoples out of context. They were not ensconced in market or battle scenes. Instead, they were each presented as an ideal manifestation of a social category, suggesting that the world of peoples could be classified

${ }^{126}$ Hodgen, Early Anthropology, chapters I0-12; Edward W. Said, Orientalism (New York: Vintage, I979); George W. Stocking, Jr., Victorian Anthropology (New York: Free Press, 1987).

${ }^{127}$ Ussama Makdisi, 'Ottoman Orientalism', American Historical Review I07, no. 3 (2002): 768-96.

${ }^{128}$ Frank Dikötter, The Discourse of Race in Modern China (Oxford: Oxford University Press, 20I5), chapter 4 .

129 Thongchai Winichakul, 'The Quest for "Siwilai": A Geographical Discourse of Civilizational Thinking in the Late Nineteenth and Early Twentieth-Century Siam', Fournal of Asian Studies 59, no. 3 (2000): 528-49; Thongchai Winichakul, 'The Others Within: Travel and Ethno-Spatial Differentiation of Siamese Subjects I885-1910', in Civility and Savagery: Social Identity in Tai States, ed. Andrew Turton (London: Curzon, 2000): $38-62$. 
into discrete types and represented in a sorted or tabular format. This reflected an emerging ethno-categorical consciousness. Like contemporaneous artists and writers in the European colonies and major port cities of Asia, Siam's literati had begun to envision social categories as fixed, bounded, and mutually exclusive.

Despite the newly comparative formatting, however, the factors used to categorize peoples - visually or descriptively - were hardly systematic. The results of these mid-nineteenth-century efforts to depict, describe, and define peoples show us just how messy the process of differentiation was in practice. ${ }^{130}$ Sometimes Bangkok's artists and writers represented difference by depicting a distinctive physical appearance or style of clothing. Sometimes they identified a people as having in common a single political affiliation or geographical origin. Or they asserted that a people could be distinguished by their religious and ceremonial practices, their typical occupations and behaviour, or their language. Countless permutations of markers were deployed in these mid-century works, but no one kind of marker alone sufficed to differentiate all peoples into distinct and bounded groups. In this sense, representations of alterity were malleable and contradictory. The markers selected to represent peoples varied considerably, even as particular markers were tenaciously applied to certain peoples again and again. The stability of the caricatures over time served an important function. Social categories were reified by the constant repetition of memorable markers of differentiation.

It was not just the markers that hearkened back to older representations of alterity in Siam. Despite their exposure to foreign compositions and interlocuters, Bangkok's mid-nineteenth-century artists and authors also built on conventional forms of expression imbued with familiar meanings. The practice of painting portraits of archetypal peoples on the shutters at Wat Pho, for example, grew out of an older tradition of depicting foreigners as temple guardians. The stanzas and statues expanded on pre-existing efforts to display knowledge for public consumption. Even Bradley's dictionary, written by two 'Siamese scholars', resembled other works of reference produced locally to respond to the growing population of readers.

${ }^{130}$ On the importance of studying ethnic identification in action, see Rogers Brubaker, Ethnicity without Groups (Cambridge: Harvard University Press, 2004). Early modern patterns of self-identification by peoples in a different context - around the Straits of Melaka - are traced by Leonard Y. Andaya, Leaves of the Same Tree: Trade and Ethnicity in the Straits of Melaka (Honolulu: University of Hawai'i Press, 2008). 
By distinguishing peoples with traditional markers and by representing alterity in familiar ways, Bangkok's artists and writers domesticated their comparative repackaging of the diversity of the world's peoples. 'The new survives when tamed by normalcy', as Mary Elizabeth Berry puts it. ${ }^{131}$ As a result, the peoples of the world offered up for comparison in mid-century Bangkok retained a distinctly local hue. At the same time, however, by adopting comparative formats to assert intellectual control over the world's peoples, everyday agents of intellectual change participated in a conceptual trend that was spreading across the globe. By representing the peoples of the world as constituting fixed, comparable, and knowable categories, Bangkok's artists and writers foreshadowed forms of ethnic identification now associated with the modern world.

${ }^{131}$ Mary Elizabeth Berry, '(Even Radical) Illustration Requires (Normalizing) Convention: The Case of 'Genre Art' in Early Modern Japan', Journal of Visual Culture 9, no. 3 (2010): 348 . 